Historia i Polityka

Półrocznik poświęcony myśli politycznej i stosunkom międzynarodowym

Nr $10(17) / 20139-43$

DOI: http://dx.doi.org/10.12775/HiP.2013.011

Wojciech Kapica (Instytut Historii Polskiej Akademii Nauk w Warszawie)

\title{
O cywilizacyjny awans Polski Roman Dmowski wobec idei modernizacji Polski 1918-1939
}

\author{
For a civilizational development of Poland \\ Roman Dmowski in the face of the idea of modernization of Poland 1918-1939
}

The Roman Dmowski's propositions of modernization of interwar Poland (1918-1939) can not be considered in terms of theories of modernization created after 1945 as a coherent, logic systems. For Dmowski the modern (modernized) Poland would be a „efficient” state with capitalist economy, free market and the respect for private property, with reduced social legislation, with developed industry and agriculture, with a strong middle class, with restricted bureaucratic machine; a national state with restricting the rights of national minorities, with low number of Jews, with the limiting the powers of the legislature and a strong executive, with association polishness with catholicism and strong emphasis on the presence of catholic religion in social life. Some ideas of Dmowski were not bad (e.g. save money and reduction of excessively developed bureaucratic machine, the development of industry and agriculture, the fight against speculation), however, the proposals were often too vague or unclear or were remarkably oriented to the free market and for this reason had no chance of implementation and popularity in the atmosphere of the 20s and 30s in interwar Poland (e.g. proposal of reduction excessively developed social legislation), some of proposals were expressly anti-Semitic. Similarly, in the area of the Polish political system and political life Dmowski offered „positive” solutions (recovery and moralisation of Polish political life, raising the niveau of political culture of the Polish political elites and Polish society, strengthening of executive power) and „negative” proposals (association polishness with catholicism and his instrumental use, desire to make Poland a national state, desire to move away from the rule of parliamentary, postulate of removing the excess of the Jewish population in Poland). The least controversial were proposals in the sphere of social and mental modernization of the Polish society (attachment to the rule of law, the cultural and civilizational raising of lower strata and classes, care for a family - according to Dmowski important institution for society, increasing hard work / diligence of the Polish population, learning of positive competition or skills competition, development of the awareness of the Polish population concerning social and economic problems, emphasis on its own - Polish creativity). It is impossible unambiguously assess all Dmowski's proposals of Poland's modernization - they were characterized by - similar to entire creative achievements of Dmowski - some „duality” - controversional ideas were mixed with interesting concepts, sometimes original. 
Słowa kluczowe: modernizacja Polski, nacjonalizm polski, myśl polityczna nacjonalistów Keywords: modernization of Polish, Polish nationalism, nationalist political thought

Problematyka stosunku obozu narodowego i jego ideologów do nowoczesności czy też do kwestii modernizacji Polski znalazła już odbicie w pracach naukowych. Krzysztof Kawalec czy Piotr Koryś pisali o wizjach modernizacji obozu narodowo-demokratycznego ${ }^{1}$. Nieco informacji przyniosły biografie Dmowskiego pióra wspomnianego już Krzysztofa Kawalca i Romana Wapińskiego² czy synteza dziejów polskiej myśli politycznej w latach 1918-1939 autorstwa pierwszego ${ }^{3}$. Stosunkiem autora Myśli nowoczesnego Polaka do nowoczesności (głównie do sfery polityki i przemian politycznych oraz kwestii dotyczących narodu) zajmowała się także Ewa Maj ${ }^{4}$. Ogólnie rzecz ujmując dotychczas historiografia polska albo pomijała kwestie idei modernizacyjnych i wizji przyszłej Polski w pisarstwie Romana Dmowskiego po 1918 roku albo skupiała się jedynie bądź na ogólnym zreferowaniu jego niektórych poglądów w tej kwestii - niejako „przy okazji” omawiania wizji modernizacji Polski całego obozu narodowego bądź na jego poglądach, które prezentował przed 1918 rokiem (książka Myśli nowoczesnego Polaka). Brakowało dokładnego, szczegółowego artykułu poświęconego pomysłom modernizacyjnym Dmowskiego po 1918 roku. Celem niniejszego (niewyczerpującego absolutnie zagadnienia!) artykułu jest zbadanie koncepcji przywódcy obozu narodowego unowocześnienia odrodzonej w 1918 roku Polski: jaka była jego wizja modernizacji Polski?

Termin modernizacja, tak modny w ostatnim półwieczu, jest wieloznaczny i różnie rozumiany przez rozmaite nauki społeczne (historia, socjologia, ekonomia). Piotr Sztompka wyróżnił trzy definicje terminu modernizacja: (1) modernizacja jako synonim „wszystkich rodzajów postępowej zmiany społecznej, w której spo-

K. Kawalec, Narodowa Demokracja wobec procesów modernizacyjnych. Dylematy, recepty, racje, [w:] Drogi do nowoczesności. Idea modernizacji w polskiej myśli politycznej, pod red. J. Kloczkowskiego i M. Szułdrzyńskiego, Kraków 2006; P. Koryś, Jaka nowoczesność? Refleksja społeczno-ekonomiczna Narodowej Demokracji do 1926 roku jako gtos $w$ dyskusji nad potrzeba i sposobem modernizacji Polski, [w:] ibidem.

2 K. Kawalec, Roman Dmowski 1864-1939, Wrocław-Warszawa-Kraków 2002; R. Wapiński, Roman Dmowski, Lublin 1989.

3 K. Kawalec, Spadkobiercy niepokornych. Dzieje polskiej myśli politycznej 1918-1939, Wrocław-Warszawa-Kraków 2000.

4 E. Maj, Pojęcie nowoczesności w pisarstwie politycznym Romana Dmowskiego, [w:] Myśl polityczna Romana Dmowskiego, pod red. J. Engelgarda, Warszawa 2009. 
łeczeństwo porusza się wzdłuż pewnej przyjętej skali postępu. Tak rozumiana modernizacja jest w pełni relatywistyczna w sensie historycznym i może być zastosowana do wszystkich okresów historycznych"; (2) rozumienie bardziej skonkretyzowane historycznie to modernizacja jako pewien proces dochodzenia do „nowoczesności” przez (najbardziej rozwinięte) zachodnie społeczeństwa tradycyjne w XIX-XX wieku, jako pewien „zbiór” procesów jak industrializacja, biurokratyzacja, racjonalizacja, sekularyzacja, alfabetyzacja etc.; (3) modernizacja rozumiana bardziej pragmatycznie jako proces „doganiania” przez społeczeństwa zacofane i słabo rozwinięte wiodących, najbardziej rozwiniętych państw, które współistniały z nimi w tym samym okresie historycznym w ramach społeczeństwa globalnego 5 .

Do czasów Romana Dmowskiego, do okresu Polski międzywojennej chyba najbardziej odpowiednia będzie definicja (1) modernizacji rozumianej jako każdy rodzaj postępowej zmiany społecznej - oczywiście w tym przypadku idee modernizacji (unowocześnienia) Polski były zrelatywizowane do wizji świata i człowieka (światopoglądu), norm i wartości, jakie wyznawał Dmowski, do jego wizji postępu i nowoczesności. Truizmem jest zdanie, że to, co dla przywódcy endecji wydawało się „,nowoczesne”, „postępowe” np. w sferze polityki czy ustroju, dla innych polityków czy partii - przykładowo dla PPS - było oznaką zacofania i „wstecznictwa”. Można pogrupować skąpe poglądy Dmowskiego w kwestii unowocześnienia Polski na te odnoszące się do gospodarki, polityki i ustroju państwa, do społeczeństwa, mentalności etc.

Wypada nadmienić, że swoje poglądy względem modernizacji państwa polskiego Dmowski zawarł już przed 1918 rokiem, nade wszystko (choć nie tylko) w książce, która stała się „biblią” obozu narodowo-demokratycznego, a później narodowego, a mianowicie w „Myślach nowoczesnego Polaka”. Autor tego niezwykłego w dziejach polskiej myśli politycznej traktatu w swych deliberacjach wyszedł od złego stanu mentalnego Polaków - krytykował ich (a właściwie elity) za brak zrozumienia własnego narodu, brak właściwego myślenia politycznego (trzeźwego, realnego, w kategoriach tzw. Realpolitik) ${ }^{7}$, za zbyt małą znajomość

5 P. Sztompka, Socjologia zmian społecznych, Kraków 2005, s. 130 i n.

6 Okres życia i działalności Romana Dmowskiego na przełomie XIX i XX wieku bardzo gruntownie przebadał Grzegorz Krzywiec, por. G. Krzywiec, Szowinizm po polsku. Przypadek Romana Dmowskiego (1886-1905), Warszawa 2009. Przed rokiem 1918 wielu ludzi, niezwiązanych nigdy dłużej albo wcale z endecją było zafascynowanych książką „Myśli nowoczesnego Polaka” do takich osób należał także późniejszy premier generał Władysław Sikorski, por. R. Wapiński, Narodowa Demokracja 1893-1939. Ze studiów nad dziejami myśli nacjonalistycznej, Wrocław-Warszawa-Kraków-Gdańsk 1980, s. 82.

7 R. Dmowski, Myśli nowoczesnego Polaka, Warszawa 1934, s. 31. 
samych siebie i zbyt rzadką autorefleksję, za nieznajomość świata, brak wiedzy o nim, za złe wychowanie młodych Polaków, za „miękkość”, łagodność, za brak ofiarności, poświęcenia dla ojczyzny, za brak wyrobienia politycznego, znajomości polityki ${ }^{8}$. Jakie recepty sugerował?

Przede wszystkim najważniejsze były zmiany (modernizacja) w sferze mentalnej - postulował wzrost liczby ludzi „rozumiejących interes narodowy i poczuwających się do obowiązku jego obrony. Postęp w tym kierunku już się zaczął i patriotyzm nasz stopniowo zamienia się w kierunek nowoczesny, pod względem żywotności zdolny mierzyć się z odpowiednimi kierunkami u innych narodów"; wzrost aktywizmu narodowego (dynamizmu) - zwiększenie udziału średnich i niższych warstw społeczeństwa w życiu narodu (każdy wedle Dmowskiego powinien być obywatelem odpowiedzialnym za państwo) ${ }^{10}$; zmianę myślenia politycznego Polaków - nauczenie się myślenia trzeźwego, w kategoriach twardej, czasami brutalnej Realpolitik ${ }^{11}$; podniesienie poziomu wykształcenia, poziomu cywilizacyjnego przez Polaków ${ }^{12}$; o nowy sposób myślenia - myślenie „tymi samymi kategoriami politycznymi, którymi myśli dzisiejszy człowiek cywilizowany, a mając już w ogromnym zakresie stosunków tę samą miarę dla obcych, możemy już do pewnego stopnia oceniać naszą względną wartość, siłę, przydatność do życia, zdolność do postępu, zdawać sobie sprawę z tego, na czym polega nasza odrębność, nasza indywidualność narodowa, słowem zbliżać się do określenia stanowiska, jakie wśród cywilizowanych ludów zajmujemy, i wykreślać sobie drogi przyszłego rozwoju"13, zmianę wychowania młodzieży (wpojenie przez rodzinę obowiązków względem społeczeństwa) ${ }^{14}$.

Odnosząc się do kwestii zmian natury materialnej w położeniu swego narodu, gospodarczej Dmowski często mówił o zacofaniu gospodarczym ziem i społeczeństwa polskiego i koniecznym i pilnym zadaniu "podniesienia materialnych zasobów"15. W przemianach społecznych i gospodarczych dokonujących się na zie-

8 Ibidem, s. 38, 42, 52, 56, 60, 106.

9 Ibidem, s. 89.

10 Ibidem, s. 98, 107, 116.

11 Ibidem, s. 31, 36-37. Dmowski chciał „modernizacji” narodu polskiego chyba także poprzez nauczenie Polaków, „uświadomienie” o brutalności świata, nade wszystko świata polityki, ale i gospodarki etc., o brutalnych regułach gry (odwoływał się tu do przykładu Prus i ich polityki) (s. 34-35).

12 Ibidem, s. 23. Pisał: „[...] gdzie inni czerpią natchnienie z cyfr i faktów, przestaniemy szukać wskazówek... w poezji”.

13 Ibidem, s. 40.

14 Ibidem, s. 55.

15 Ibidem, s. 30. Pisał: „Naród nasz pod względem siły materialnej, pod względem liczebności i bogactwa, daleko pozostał poza tymi ludami, które postanawiają dziś głównie o losach świata, i podniesienie materialnych zasobów jest jednym z pilniejszych i donioślejszych zadań naszego bytu”. 
miach polskich w XIX wieku widział środek do przeobrażen „duchowych” narodu polskiego, Polaków, do wzmocnienia narodu, który znów stworzy silne państwo liczące się w cywilizacyjnym współzawodnictwie narodów ${ }^{16}$. Był zdania, że przemiany gospodarcze i społeczne w Królestwie Polskim wpłynęły na wytworzenie się typu Polaka przedsiębiorczego, czynnego, aktywnego; wskazuje, że na skutek zniesienia pańszczyzny przemiany w największym stopniu dotknęły ludność wiejską ${ }^{17}$. Przywódca obozu narodowo-demokratycznego głosił hasło rywalizacji, współzawodnictwa między narodami ${ }^{18}$. Rozumiał je jako nieuchronne uwarunkowanie egzystencjalne - nie możliwe do przezwyciężenia na żadnym etapie biegu historii. W końcowej partii swej książki Dmowski zawarł ważne słowa: „My, jeżeli jako naród chcemy żyć, jeżeli chcemy spełnić swój obowiązek względem ludzkości i nie pozostawić po sobie marnego wspomnienia na kartach dziejowych, musimy iść naprzód, tworzyć, organizować według swego typu wszystko, co jest zdolne ulec naszemu wpływowi. Gdybyśmy nigdy nie odzyskali bytu państwowego, a co za tym idzie i cywilizacyjnie z czasem zginęli, bylibyśmy przykładem narodu, który zmarniał, nie doszedłszy do dojrzałości - jednym z najmniej zaszczytnych przykładów w historii. [...] Musimy żyć, rozrastać się, rozwijać działalność na wszystkich polach, musimy dążyć do tego, by zostać silnym, niezwyciężonym narodem. Tam, gdzie możemy pomnożyć swe siły i swą pracę cywilizacyjną, wchłaniając inne żywioły, żadne prawo nie zabrania nam tego, ale czynić to mamy nawet obowiązek" ${ }^{19}$.

Główne idee, postulaty modernizacyjne zawarte w „Myślach nowoczesnego Polaka” były związane bądź ze sferą mentalną, a raczej jej gruntowną zmianą (aktywizm narodowy, dynamizm, patriotyzm etc.) bądź ze sferą materialną (bogacenie się, pomnażanie zasobów narodowych). Warto jeszcze wskazać na jedną kwestię związaną z „Myślami nowoczesnego Polaka”. Dmowski napisał, że „naród nasz korzystał ciągle z doświadczenia, zasobów duchowych, z pracy wiekowej innych ludów, które go wyprzedziły w cywilizacji. W stosunku do tego, co wziął, dał dotychczas ludzkości bardzo mało”. Wysuwał zatem postulat dążenia do podniesienia narodu polskiego na wyższy szczebel rozwoju cywilizacyjnego, na

16 Ibidem, s. 50-51. Dmowski komentował owe przemiany „Przemiany prawne, postęp ekonomiczny upodabniają nasz kraj innym krajom europejskim. Zaczyna się wytwarzać podobny do swych odpowiedników w innych społeczeństwach typ polskiego kupca, przemysłowca, technika, kantorzysty itd.; na roli nawet zamiast pana - szlachcica zaczynają się zjawiać w niezupełnie jeszcze czystej postaci typy nowoczesne: agrariusz - wielki producent i mniejszy - farmer” (s. 49).

17 Ibidem, s. 64

18 Ibidem, s. 98, 109. Przykładowo wedle Dmowskiego ostra rywalizacja w dziedzinie gospodarczej, społecznej, walki o byt między Polakami a Niemcami w zaborze pruskim spowodowała zahartowanie wielu Polaków, nauczenie się przez nich twardej, codziennej walki (s. 58-59).

19 Ibidem, s. 114-115. 
tyle wysoki szczebel, ,ażeby od nas brano w przyszłości tak, jak myśmy brali od innych i jak dziś bierzemy”. Uważał to za „najlepiej pojęty obowiązek względem ludzkości” ${ }^{20}$, zaś w innym miejscu odpowiadając a zarzut jednego z czytelników, że rzekomo pragnął on: „zatrzeć, wytępić w narodzie naszym wszystko, co stanowi jego odrębność, a życie jego i postępowanie wzorować w zupełności na innych narodach”. Dmowski wskazał więc słusznie, że w ówczesnym świecie powstały takie zwyczaje, z których „żadnemu ludowi bezkarnie wyłamywać się nie wolno”. Słusznie wskazuje, że byłoby czymś niedorzecznym, dziwnym, gdyby jakiś naród dla zachowania swojej odrębności „nie chciał zaprowadzić u siebie kolei żelaznych, telegrafów lub służby bezpieczeństwa”. Twierdził, że nie można wszystkich różnic od innych narodów traktować jako cnót i pisał: "Jesteśmy niewątpliwie brudniejsi i leniwsi od narodów zachodnich — czyż mamy przeto nasz brud i nasze lenistwo w dalszym ciągu pielęgnować?" 21.

Poglądy Romana Dmowskiego 22 , jak i większości obozu politycznego, którego był przywódcą (abstrahując od „odchyleń” różnych grup, które zwłaszcza w latach 30. zerwały z obozem narodowym) w kwestiach gospodarczych charakteryzował liberalizm gospodarczy, nastawienie antylewicowe ${ }^{23}$. Zdaniem większości ówczesnych uczestników życia politycznego (także w endecji) Dmowski znał się słabo na sprawach gospodarczych ${ }^{24}$. Uważał on, że kryzysy gospodarcze lat 20. i 30. (kryzys powojenny; wielki kryzys gospodarczy 1929-1933/5) nie mają charakteru cyklicznego (jak uważało wielu ekonomistów z Johnem Maynardem Keynesem na czele, którego nota bene Dmowski lekceważył i z którego drwił na kartach swoich prac), lecz są zjawiskiem trwałym, zwłaszcza w odniesieniu do Europy. Podkre-

20 Ibidem, s. 28.

21 Ibidem, s. 22.

${ }^{22} \mathrm{~W}$ artykule zająłem się jedynie analizą idei Dmowskiego odnośnie modernizacji Polski po 1918 roku, nie badając kwestii recepcji owych poglądów w okresie międzywojennym i po 1945 roku.

23 Piotr Koryś wymienił kilka kluczowych punktów endeckiego programu zmodernizowania Polski w kwestiach gospodarczych, które w dużej mierze „pokrywały się” z poglądami Dmowskiego na modernizację gospodarki, a mianowicie: (1) współdziałanie klas i warstw społecznych - budowanie nowoczesnego polskiego narodu ponad podziałami; (2) oparcie rozwoju gospodarki nie tylko na jednostkach, ale także na rodzinie; (3) praworządność i uczciwość w działaniach państwa; (4) rezygnacja z etatyzmu; (5) włączenie Polski w obręb gospodarki światowej, ale z uwzględnieniem jej żywotnych interesów; (6) rozwój przemysłu; (7) reforma stosunków własnościowych na wsi; (8) uporządkowanie finansów publicznych i usprawnienie ich zarządzaniem, por. P. Koryś, op. cit., s. 90.

24 R. Wapiński, Roman Dmowski, s. 325. Zdaniem autora poglądy ekonomiczne Dmowskiego napotykały opór ekonomistów, w tym także związanych z endecją jak chociażby Romana Rybarskiego. Dmowski krytykował wówczas Rybarskiego i Adama Heydla, por. ibidem, s. 357. 
ślał również dynamiczny rozwój innych kontynentów i czołowych tamtejszych państw jak Japonia, Chiny, Stany Zjednoczone Ameryki, Brazylia.

Dmowski był zwolennikiem „taniego”, oszczędnego państwa, był przeciwny zatem rozbudowanemu ustawodawstwu socjalnemu, którego podwaliny $\mathrm{w}$ niepodległej Polsce położono w latach 1918-1919. Krytykował ex post ówczesne elity rządzące za jego wprowadzenie, za nadmiernie wydawanie publicznych pieniędzy; uważał, że trzeba było wówczas rozsądnie i skromnie administrować publicznymi pieniędzmi. Podkreślał, że każdy Polak indywidualnie w warunkach 1918 roku i kolejnych lat miał żyć oszczędnie i pracowicie ${ }^{25}$.

W 1925 roku i później Dmowski akcentował konieczność oszczędności, pracowitości oraz wspierania polskiego przemysłu i rolnictwa : „[...] jesteśmy narodem bez kapitału, bez gotówki, konieczną jest oszczędność. [...] Polacy zawsze wydają więcej pieniędzy na pokazanie się, niż na użycie. [...] My jeszcze dziś sypiemy pieniędzmi ogromnie, choć narzekamy na ciężkie czasy, trzeba więc nauczyć się oszczędzać. Praca i oszczędność [...] musi już całe społeczeństwo wziąć się do pracy. Programem społeczeństwa musi być dążenie do tego, żeby naród jak najmniej spożywał produktów z zagranicy i żeby jak najwięcej mógł sprzedawać, a wtedy będziemy mieli i gotówkę i kredyt”26. Motyw „oszczędnego” państwa i oszczędności będzie się pojawiał w pismach Dmowskiego wielokrotnie. Zagrożenie w wydatkach państwowych i prawidłowym gospodarowaniu widział w okradaniu państwa, w różnego rodzaju nadużyciach, spekulacjach, marnotrawstwie i podkreślał pozytywną rolę opinii publicznej, społeczeństwa w walce z patologiami ${ }^{27}$. Kolejny aspekt oszczędzania to zdaniem Dmowskiego (1926 rok) ograniczenie biurokracji, zmniejszenie liczby urzędów i urzędników, a urzędnicy niezbędni muszą jego zdaniem pracować jeszcze intensywniej: „Trzeba poznosić całe wydziały, nawet całe ministerstwa niektóre, w innych zmniejszyć znacznie liczbę urzędników, przy możliwym uproszczeniu naszej machiny administracyjnej i zmuszeniu pozostałych funkcjonariuszy do dawania większej i produkcyjniejszej pracy. Zwiększy się liczba ludzi bez zajęcia - to trudno: jeżeli państwo polskie w tych warunkach, co dzisiejsze, ma istnieć, organizacja machiny państwowej musi być organizacją intensywnej i pożytecznej pracy, a nie przytułkiem dla ludzi, którzy nie mają się gdzie podziać”. Uważał, że: „[...] same oszczędności nas nie uratują, jeżeli się nie zwiększy siła podatkowa kraju, jeżeli dochody państwa miast rosnąć będą spadały. Do podwyższenia zaś siły podatkowej kraju prowadzi tylko jedna droga: wzrost

\footnotetext{
25 Pisma, T. IX: Polityka narodowa w odbudowanem państwie, Częstochowa 1939, s. 22-23

26 Ibidem, s. 27.

27 Ibidem, s. 268-269.
} 
wytwórczości. Polska będzie upadała wraz z upadkiem produkcji - z chwilą, gdy produkcja zacznie rosnąć, Polska będzie rosła”. Podobnie pisał w innym miejscu, wskazując, aby „podnieść siłę podatkową kraju, a zmniejszyć rozchody państwowe. $\mathrm{Na}$ drogę oszczędności wchodzimy, ale to jest dopiero słaby początek i nie można powiedzieć, żeby pod względem kierunku najlepszy. Oszczędność zdrowa musi przede wszystkim usunąć z rozchodów państwowych wszelkie nieprodukcyjne marnotrawstwo i wszelki rabunek grosza publicznego". Jako polityk polskiej prawicy miał na myśli m. in. wojsko i zalecał, chociażby uproszczenie administracji, zniesienie niepotrzebnej biurokracji, usunięcie niepotrzebnych urzędników i funkcjonariuszy w armii ${ }^{28}$.

Dużo uwagi przykładał przywódca narodowej demokracji do kwestii bezrobocia. Pisał, że jest to „jedna z naczelnych kwestii naszego położenia: wymaga ona wielkiego skupienia uwagi i wysiłków. Grozi tym, że stanie się czynnikiem rozkładu naszego zdrowia społecznego i naszej siły państwowej" ${ }^{29}$. Co konkretnie proponował Dmowski odnośnie walki z bezrobociem w Polsce międzywojennej? W 1926 roku zaproponował m. in.: zmniejszenie zakresu robót publicznych dla bezrobotnych, aby nie brakowało pieniędzy na inwestycje; redukcję nadmiernej jego zdaniem liczby urzędników w Polsce, w celu zaoszczędzenia pieniędzy państwowych; ograniczenie pośrednictwa w handlu (co uderzyłoby głównie, choć nie tylko, w ludność żydowską!); zmniejszenie kosztów produkcji; ograniczenie płac niektórych robotników (z tzw. arystokracji robotniczej); zwiększenie wydajności pracy i czasu pracy. Były to raczej liberalne i wolnorynkowe postulaty, zresztą niezbyt sprecyzowane ${ }^{30}$.

Motyw walki z pośrednictwem handlowym, spekulacją, finansjerą pojawiają się wielokrotnie. Czy niechęć Dmowskiego do pośredników, finansistów, spekulantów brała się tylko z jego antysemityzmu i faktu, że gros przedstawicieli tych grup społecznych w Polsce międzywojennej był narodowości żydowskiej, czy może także była związana z jego pochodzeniem społecznym (drobnomieszczańska rodzina, surowi i ciężko pracujący rodzice)? ${ }^{31}$. A może była to kombinacja obydwu czynników? Dmowski pisał krytycznie (1926): „Nacisk ten i ta kontrola potrzebne są przede wszystkim w stosunku do przedsiębiorców w przemyśle i handlu. Trze-

28 Ibidem, s. 211-213.

29 Pisma, T. X: Od Obozu Wielkiej Polski do Stronnictwa Narodowego, Częstochowa 1939, s. 26.

30 Pisma, T. IX, s. 198, 200, 206, 221.

31 Wszyscy biografowie Dmowskiego (Krzysztof Kawalec, Roman Wapiński, Andrzej Micewski) podkreślają pewien wpływ domu rodzinnego na Dmowskiego i jego poglądy, zwłaszcza w sferze społecznej i obyczajowej, por. K. Kawalec, Roman Dmowski.., s. 8 i nn; R. Wapiński, Roman Dmowski, s. 17 i nn, A. Micewski, Roman Dmowski, Warszawa 1971, s. 18 i nn. 
ba wytępić metody spekulacyjne, rozbójnicze, usunąć marnotrawstwo, kosztowne utrzymywanie próżniaków lub półpróżniaków, zmusić przemysł i handel do wysiłku w ścisłym dostosowaniu się do potrzeb kraju. Niech przedsiębiorczość pójdzie w tym kierunku, a nie w kierunku rabowania skarbu lub obdzierania ludności, jak się to dotychczas w szerokim zakresie działo. Państwo musi zrobić wysiłek na tej czy innej drodze ku zorganizowaniu kredytu, ale kredyt ten powinno mieć bezpośrednio w swoich rękach i uczynić z niego narzędzie do popierania tych przedsiębiorstw, które się zadawalniają uczciwym zyskiem, mają oszczędną administrację, dobrą organizację pracy, które wreszcie w swej produkcji przystosowane są ściśle do potrzeb kraju lub rynku zewnętrznego. Niech uczciwa, inteligentna i wytężona praca korzysta z poparcia państwa; to, co nie zasługuje na poparcie, niech ginie"32. Widać, że chciał, aby państwo zajęło się kontrolą przedsiębiorców, walką ze spekulacją, marnotrawieniem, ale także organizowaniem dogodnych kredytów dla przedsiębiorców. We wzroście kosztów produkcji i w wygórowanym pośrednictwie widział przyczyny zmniejszania się polskiej produkcji, zmniejszania się rynku wewnętrznego i zwiększania się bezrobocia: „Polska stała się wielkim rynkiem dla naszego własnego przemysłu. Rynek ten wszakże szybko się kurczy z dwóch przyczyn. Pierwsze, to zubożenie ludności, która nie ma za co kupować, druga, jeszcze ważniejsza - to drożyzna produktów przemysłu, wynikająca z niesłychanego podniesienia się kosztów produkcji i pośrednictwa. [...] To podrożenie kosztów produkcji i pośrednictwa, czyniące wytwory przemysłu coraz mniej dostępnymi dla ludności, zmniejsza szybko ich konsumpcję na wewnątrz, co obniża kulturę kraju, i możność wywozu na zewnątrz, bo drogi nasz produkt nie wytrzymuje konkurencji z innymi. W rezultacie mamy zmniejszanie się produkcji i zwiększanie liczby bezrobotnych" 33 .

Inny aspekt modernizacji gospodarki, polskiego życia gospodarczego według Dmowskiego to ograniczenie roli związków zawodowych, reorganizację organi-

32 Pisma, T. IX, s. 220.

33 Pisma, T. X., s. 26. Dmowski uważał, że jest możliwe podźwignięcie produkcji: „Kraj, posiadający blisko 30 milionów ludności, w ogromnej przewadze rolniczej, której potrzeby przy stopniowym ulepszaniu gospodarki rolnej stale rosną, a obok tego mający duże bogactwa surowców, mający swój węgiel i naftę, może utrzymać wcale duży przemysł na swoje wewnętrzne potrzeby. Tylko trzeba, żeby przy danej wydajności ziemi, przy istniejącej cenie produktów rolnych cena produktów przemysłowych była dostępna dla rolnika. A tę cenę produktów przemysłowych można ogromnie obniżyć wobec tego, że ona jest sztucznie wyśrubowana przez nieuczciwą spekulację kupców i przemysłowców, przez nieuzasadnione niczym powiększenie kosztów organizacji i administracji przemysłu i handlu, wreszcie przez nieuzasadniony potrzebami ludności robotniczej, rozrost tzw. zdobyczy społecznych, przez ogromne obniżenie wydajności pracy i nadmierne zwiększenie w pewnych jej gałęziach pobieranej za nią zapłaty”, (Pisma, T. IX, s. 213-214). 
zacji społecznych jak kasy chorych, kasy emerytalne, reorganizację ustawodawstwa społecznego, które zostało „bezmyślnie” zaadaptowane z Zachodu: „Wreszcie nasze ustawodawstwo społeczne, nie wyrosłe z potrzeb kraju i jego ludności, ale będące poronionym płodem bezmyślnego naśladownictwa, musi podlec głębokim zmianom" ${ }^{34}$. W pracy Anglia powojenna $i$ jej polityka Dmowski w związku z rozważaniami o przeludnieniu wsi i negatywnych tego skutkach wysunął postulat modernizacyjny dla Polski w dziedzinie rolnictwa: należy podnieść wytwórczość rolniczą na drodze udoskonalenia sposobów uprawy roli35.

Po przewrocie majowym zaczął Dmowski wyraźnie głosić hasła samodzielności gospodarczej Polski (jakby nie widział, że zamiast gospodarczego „odgradzania” się państw, ma miejsce coraz większe „zacieśnianie się” więzi gospodarczych między państwami), stworzenia właściwej polityki gospodarczej ${ }^{36}$, aktywizacji biernych dotąd sfer gospodarczych i prowadzenia przez nie właściwej polityki gospodarczej (okazanie patriotyzmu, poświęcenie). Dmowski oceniał te sfery krytycznie - podkreślał niedojrzałość charakteru polskich sfer gospodarczych, słabość polskiego przemysłu i handlu, brak właściwych, dobrze wykształconych ludzi z szerszym spojrzeniem, zwłaszcza wśród ziemian, którzy nie myśleli o przyszłości ${ }^{37}$. Autor Myśli nowoczesnego Polaka widział wielką rolę w kształtowaniu polityki gospodarczej „sfer politycznych”. Widział to następująco: „Na to, żeby umieć dać krajowi należytą politykę gospodarczą, w dzisiejszej dobie wielkiego przełomu, trzeba olbrzymiej pracy, dużych studiów nad tym, co się u nas i poza nami dzieje, a przede wszystkim trzeba umieć patrzeć i myśleć, trzeba wreszcie wielkiej energii w organizacji, w przezwyciężaniu przeszkód [...] trzeba wielkiego patriotyzmu, wielkiego poświęcenia dla przyszłości narodu"38. Podkreślał, że ówczesna (1930 rok) polityka państwa „[...] stara się zniszczyć resztki własnego kapitału drogą systemu podatkowego i obarczenia go innymi ciężarami, możliwymi do zniesienia, i to dziś z wielkim trudem, tylko w krajach bardzo bogatych". Jedyny ratunek

34 Ibidem, s. 225.

35 R. Dmowski, Anglia powojenna i jej polityka. Uwagi ogólne, Warszawa 1926, s. 68.

36 Pisma, T. IX, s. 152. Dmowski pisał: „Do osiągnięcia tego celu nie doprowadzi nas płytkie naśladowanie tego, co się gdzie indziej robi. Nie doprowadzi nas wzmacnianie i rozwijanie polityki klasowej, po pierwsze dlatego, że ta już na Zachodzie wykazuje swoje bankructwo, po wtóre dlatego, że przy stanie kulturalnym znacznej części naszej ludności polityka klasowa przybiera u pewnych żywiołów naszego kraju postać dzikiej walki na noże, nie znającej żadnego hamulca. Między robotnikiem angielskim, odstępującym od strajku powszechnego, gdy mu dowiedziono, że ten jest nieprawny, a posłem na Sejm u nas, który wzywa do odbierania gwałtem cudzego mienia, istnieje duża odległość".

37 Pisma, T. VII: Świat powojenny i Polska, Częstochowa 1937, s. 56-57.

38 Ibidem, s. 57. 
widział w pożyczkach zagranicznych ${ }^{39}$. Pisał krytycznie o polityce marnotrawienia publicznych pieniędzy i przeszkadzania prywatnej inicjatywie gospodarczej. Za złą sytuację gospodarczą Polski obwiniał także samych Polaków, za ich brak wiedzy, brak właściwego, obywatelskiego stosunku do zagadnień gospodarczych, egoizm, prywatę $e^{40}$.

Wybuch wielkiego kryzysu gospodarczego na świecie (1929-1933) i w Polsce (1930-1935) spowodował chyba zaostrzenie optyki spojrzenia Dmowskiego na zagadnienia gospodarcze w kierunku jeszcze bardziej liberalnym. Należy zgodzić się z sądem Krzysztofa Kawalca, że gdy większość świata (na czele z „bastionami” liberalizmu gospodarczego Wielką Brytanią i USA) znajdowała receptę na problemy wielkiego kryzysu gospodarczego w postaci rozbudowy, rozrostu funkcji państwa w sferze gospodarczej i społecznej, to Dmowski postulował rozwiązania przeciw$n \mathrm{e}^{41}$. Jeszcze silniej niż wcześniej akcentował samowystarczalność gospodarczą Polski i jej „odgrodzenie się” od zagranicy: „[...] świetne czasy handlu światowego już minęły, że narody, nawet te, które do tego najmniej mają warunków, szukają w nowym położeniu gospodarczym ocalenia w programie samowystarczalności, że i my na tej drodze musimy szukać wyjścia. [...] Trzeba mieć politykę gospodarczą, która nie byłaby jedynie niezdarną łataniną z dnia na dzień, ale która by miała przed sobą wyraźny cel, plan na szereg lat nakreślony, do swego celu konsekwentnie zmierzała i choć powoli go urzeczywistniała" ${ }^{2}$. Pisał: „Jedyny, logiczny wniosek [...] daleko idące obniżenie kosztów utrzymania państwa, redukcja machiny państwowej, jej uproszczenie, i co za tym idzie, zmniejszenie ciężarów, obarczających społeczeństwo”. Być może miał jakieś rozterki moralne: „[...] trzeba zacząć machinę państwową redukować, upraszczać, uwalniać od szeregu funkcji, którymi ją w ubiegłym okresie obarczono. Łatwo to powiedzieć. Te funkcje, które dziś spełnia państwo ze wszystkimi instytucjami, składającymi się na jego ustrój, zaspakajają potrzeby kultury, postępu, higieny, wygody, materialnego zabezpieczenia niezdolnych do pracy, czy nie mogących jej znaleźć itd. Jakże można zrzekać się tych rzeczy ?... Istotnie to pytanie ciężkie. Ale wiele ten może, kto musi. Jeżeli pod naciskiem konieczności deklasują się jednostki i rodziny, dlaczego nie mają deklasować się narody ?...”³. Dalsze słowa były jeszcze bardziej radykalne: „Chcąc się ratować sku-

39 Ibidem, s. 57-58.

40 Ibidem, s. 58-59.

41 K. Kawalec, Roman Dmowski..., s. 236.

42 Pisma, T. VII, s. 71.

43 Ibidem, s. 80-82. Dmowski sądził, że wielki kryzys gospodarczy (przynajmniej dla Europy) będzie zjawiskiem trwałym, a nie przejściowym, uważał, że nie ma co liczyć na szybką poprawę położenia gospodarczego Europy i dlatego też pisał: „[...] jedynym wyjściem z położenia, w jakim 
tecznie, nie unikniemy zniesienia obowiązku wszelkich ubezpieczeń społecznych, zredukowania budżetów miast i powiatów do połowy, a może i więcej, wreszcie ogromnego uproszczenia administracji państwowej, bardzo poważnego zmniejszenia liczby urzędników, rozmaitych przywilejów i wygód, z których korzystają, wreszcie kosztów reprezentacyjnych. [...] Cóż z tego, że jedni będą ubezpieczeni, gdy inni skutkiem tego będą skazani na umieranie z głodu; że miasta będą pięknie przyozdobione i będą mogły gościom pokazywać rozmaite nadzwyczajne instytucje, jeżeli na ich ulicach na każdym kroku ludzie będą wyciągali ręce o jałmużnę; że wspaniale urządzone biura będą wypełnione urzędnikami, a dygnitarze będą mieli luksusowe mieszkania i będą paradowali w drogich automobilach, jeżeli już na pierwszego nie znajdzie się w kasie pieniędzy na wypłacenie im wszystkich pensji, może jedynie z wyjątkiem tych, którzy pobierają największą...”. Był zdania, że takie działania „redukcyjne” napotkają straszny opór ze strony zainteresowanych, ale także nieuczciwych przedsiębiorców, spekulantów etc. ${ }^{44}$.

W roku 1932 Dmowski wysunął inną godną odnotowania propozycję, zresztą miała ona zabarwienie wyraźnie antyżydowskie. Domagał się mianowicie ograniczenia pośrednictwa oraz udziału w handlu ludności żydowskiej: „Inna jest rzecz z donioślejszą jeszcze dla wytwórczości sprawą, ze zmniejszeniem kosztów pośrednictwa, z uzdrowieniem naszego handlu. Wymaga on uzdrowienia od samego dołu, od handlu detalicznego, często bardzo drobnego. Ci handlujący nie robią fortun, często pędzą nędzną egzystencję - główne nieszczęście polega na tym, że ich jest za dużo”. Dmowski powiadał, że Polaków-handlarzy jest mało, ale „mamy ludność nam obcą, różniącą się od nas wszystkim, prócz praw, z których korzysta - Żydów, którzy w głównej swej masie żyją z handlu i wszelkiego rodzaju pośrednictwa. Jeśli ta ogromna liczba Żydów w Polsce była zawsze nieszczęściem, to $\mathrm{w}$ dzisiejszym położeniu, przy tak wielkim przeroście liczby pośredników i stąd kosztach pośrednictwa, duszących produkcję, nieszczęście to jest dzesięćkroć większe. Ażeby Polska mogła gospodarczo żyć, ażeby wytwórczość jej nie ginęła, jeno rosła, liczba ludności, żyjącej z pośrednictwa, musi się w o wiele większym jeszcze stosunku zmniejszyć, niż liczba urzędników w państwie. Wielką dla Polski jest sprawą, ażeby się zmniejszyła kosztem pośrednictwa żydowskiego, nie zaś polskiego” ${ }^{\text {45 }}$. Inna recepta na wyjście z kryzysu to jego zdaniem: „wytępienie u nas wszelkiej spekulacji. Ta, najbardziej zabójcza z chorób życia gospodarcze-

państwo europejskie się znalazło, będzie radykalne zmniejszenie kosztów utrzymania machiny państwowej, a więc jej uproszczenie i, co za tym idzie, zmniejszenie liczby ludzi żyjących z państwa", (ibidem, s. 85-86).

44 Ibidem, s. 102-103.

45 Pisma, T. VIII: Przewrót, Częstochowa 1938, s. 66-68. 
go [...] uczyniła nasze życie gospodarcze najniezdrowszym bodaj na świecie. [...] Trzeba dokonać gruntownej rewizji naszych traktatów handlowych i naszego systemu celnego. Nie trzeba być wielkim fachowcem, żeby wykazać w nich punkty, wprowadzone tam w celu ożywienia obrotów handlu zewnętrznego i związanej z nim spekulacji ciężkim kosztem rodzimej wytwórczości”. Uważał, że „również system podatkowy trzeba przekształcić tak, żeby nie zabijał wytwórczości, zwłaszcza tej, która jest bardziej przystosowana do potrzeb kraju. Jest jeszcze wielka sprawa, bodaj najtrudniejsza ze wszystkich, bo wymagająca współdziałania szeregu państw. Jest to walka o ceny zboża i produktów rolnych"6.

Jego zdaniem wielki kryzys gospodarczy to zarazem krach „żydostwa” oraz masonerii powiązanej z Żydami, a tym samym pewne ograniczenie ich szkodliwych dla Polski wpływów ${ }^{47}$. Powiadał też, że „jednym z donioślejszych skutków kryzysu gospodarczego w naszym kraju jest to, że zredukował on ogromnie pole do walki społecznej. W kryzysie cierpi i praca, i kapitał: pracy jest coraz mniej, a kapitał stopniowo ginie. Napięcie tedy walki pracy z kapitałem musi być coraz słabsze” ${ }^{38}$.

Inny ciekawy postulat zmodernizowania Polski w sferze gospodarczej i społecznej to apel z roku 1925 do mieszczaństwa wielkopolskiego (poznańskiego) i pomorskiego o dobrowolną kolonizację miast polskich, głównie ziem byłego zaboru rosyjskiego. To mieszczaństwo było darzone przez Dmowskiego wielkim szacunkiem i poważaniem i które - jako wywodzące się z ziem b. zaboru pruskiego - było dlań wzorem zaradności, przedsiębiorczości, doświadczenia wyniesionego z lat walki gospodarczej z Niemcami w okresie zaborów. Można tu dostrzec także wątek antysemicki : wiadomo, że na ziemiach byłego zaboru rosyjskiego większość mieszczaństwa (kupcy, handlowcy, drobnomieszczaństwo) stanowiła ludność żydowska ${ }^{49}$. Do postulatu kolonizacji Dmowski powrócił w 1934, kiedy wysunął propozycję, aby młodzi ludzi, absolwenci szkół wyższych, niemogący znaleźć pracy w dużych ośrodkach miejskich, osiedlali się i znajdowali pracę na prowincji, zacofanej i odczuwającej brak pracowników umysłowych: „Kolonizując naszą zaniedbaną prowincję, znajdą pole do pracy nad kulturą kraju i wzmocnieniem organizacji jego życia" ${ }^{\circ 0}$.

Polityka i ustrój państwa to kolejne dziedziny, które zdaniem przywódcy endecji należało zmodernizować w Polsce. W 1926 roku komentując przewrót majowy, pisał o uzdrowieniu życia politycznego: „Nasze życie państwowe [...] posiada

\footnotetext{
46 Ibidem, s. 67-69.

Ibidem, s. 383.

48 Ibidem, s. 413.

49 Pisma, T. IX, s. 264.

50 Ibidem, s. 308.
} 
ogromne braki moralne i trzeba je usuwać. Ale tego nie robią i nie są zdolne robić rewolucje polityczne. To może być tylko wynikiem głębokich zmian w społeczeństwie. Jednym zaś z najważniejszych warunków naprawy moralnej życia państwowego jest podniesienie poziomu inteligencji politycznej społeczeństwa. [...] Hasłami, choćby były rzucane najszczerzej, nie umoralni się życia państwowego. Trzeba pokazać, co się zamierza i co się jest zdolnym zrobić, ażeby postęp moralny naprawdę się rozpoczął" ${ }^{1}$. Pisał o wadach polityków i sposobach ich likwidacji oraz o zadaniach polityki: „Przede wszystkim trzeba usunąć z widowni naszego życia politycznego to, co najwięcej sprzyja wytwarzania zamętu i dłuższemu jego trwaniu, co przedstawia tym samym największe dla kraju niebezpieczeństwo. Tym największym niebezpieczeństwem jest tchórzostwo ludzi, odpowiedzialnych za państwo i za postępowanie polityczne narodu [...]. Polityka, jeżeli ma być zdrową i uczciwą, dobroczynną w skutkach dla narodu, wymaga zawsze ludzi odważnych, nie bojących się nadstawiać karku za to, w co wierzą. W momentach wszakże takich, jak obecny, tchórze są wprost klęską, są żywiołem, który zgubi kraj jeżeli się losów jego z ich rąk nie wyrwie, jeżeli ich się nie usunie z frontowych linii naszego życia i naszych walk politycznych" 52 . Definiował ludzi, z właściwymi cechami i przymiotami do uczestnictwa w życiu politycznym (ludzie mający silną wiarę, odwagę bronienia swoich poglądów, sumienni, mężni, umiejący zachować zimną krew i przytomność umysłu, pełni poczucia odpowiedzialności $)^{53}$.

Jak wiadomo, Dmowski nie był admiratorem parlamentaryzmu w wydaniu polskim lat 1919-192654. Krytykował mocno polskie życie polityczne - mówił o braku rozwiniętej myśli państwowej w Polsce, wskazywał na słabość, nietrwałość, niestabilność polskiej polityki, polskiego życia politycznego, krytykował partyjniactwo, partie polityczne, ich ilość i rozdrobnienie ${ }^{55}$. Uważał, że „żeby nasze ciała prawodawcze były zdolne naprawdę do pracy twórczej, budującej potęgę

51 Pisma, T. X, s. 40.

52 Ibidem, s. 46.

53 Ibidem, s. 49.

54 K. Kawalec wskazuje na Dmowskiego nieumiejętność dostosowania się do reguł gry w systemie demokratycznym oraz jego rozczarowanie do parlamentaryzmu, por. K. Kawalec, $\mathrm{Na}$ rodowa Demokracja wobec faszyzmu 1922-1939. Ze studiów nad dziejami myśli politycznej obozu narodowego, Warszawa 1989, s. 96-97. W innym miejscu K. Kawalec trafnie ujął pewien problem: „W spuściźnie publicystycznej Dmowskiego sporo tekstów pisanych jest z myślą o wielu adresatach; po wojnie, zwłaszcza zaś po 1926 r., analogiczne wysiłki Dmowskiego były tym trudniejsze, że pogłębiły się w obrębie jego środowiska rozbieżności poglądów. Szczególnie widoczne było to właśnie w kwestii ustrojowej. Wątek antyparlamentarny eksponował Dmowski na forum OWP oraz wśród młodzieży, natomiast w wystąpieniach obliczonych na szerszy krąg odbiorców przemawiał innym językiem, nieporównanie bardziej umiarkowanym”, por. K. Kawalec, Roman Dmowski..., s. 271.

55 Pisma, T. X, s. 54-56, 68 i n. 
państwa i pomyślny byt jego ludności, nie powinno być w nich więcej, niż dwa lub najwyżej trzy stronnictwa. Dziś, gdy losy kraju więcej się rozgrywają poza Sejmem, niż w Sejmie, to rozproszkowanie narodu jest wprost groźne. Zbyt wielka ilość organizacji jest dezorganizacją" 56.

Antidotum na bolączki życia politycznego w Polsce oraz reakcją na zamach majowy i przejęcie władzy przez Józefa Piłsudskiego było założenie Obozu Wielkiej Polski. Dmowski definiował ówczesne zadanie swojego obozu politycznego (rozwinięcie pracy w kraju, skupienie rozbitych partii i grup narodowych w jeden obóz narodowy). Przedstawiał cel: „Jest nim posiadanie silnego, na trwałych podstawach prawnych opartego państwa, zdolnego zająć należne mu stanowisko w świecie i zapewnić narodowi warunki wszechstronnego rozwoju duchowego i materialnego. Obszar naszej ziemi, nasza liczba, zasoby naszego kraju, pozwalają nam na zbudowanie takiego państwa, zasługującego na miano państwa wielkiego, ale żeby je zbudować i posiadać, musimy być z postępowania swego narodem wielkim”. W roku 1927 pisał o celach swoich i Obozu Wielkiej Polski: „Musimy uczynić Polskę zdolną do szybkiego postępu gospodarczego, centralizacyjnego i politycznego. Kto nie idzie naprzód - cofa się i gotuje sobie śmierć" ${ }^{57}$. Wypada dodać, że pierwotny zamysł pozyskania czy też „podporządkowania” dla Obozu Wielkiej Polski innych stronnictw politycznych (PSL „Piast”, Polskie Stronnictwo Chrześcijańskiej Demokracji) nie został zrealizowany.

W pracy Zagadnienie rządu zasygnalizował, że elity polityczne Polski muszą mieć głęboką myśl katolicką i polską. W innym miejscu tej pracy podkreślił rolę czynników jak religia (katolicyzm), poczucie narodowe, patriotyzm, które powinni dominować w życiu politycznym i w nich widzi lek na wiele bolączek życia politycznego, społecznego czy gospodarczego ${ }^{58}$. Sądził, że podstawowa dla zmodernizowania życia politycznego będzie zmiana mentalności, zmiana myślenia i odejście od bezrefleksyjnego naśladowania obcych wzorów, zmiana organizacji

56 Ibidem, s. 70-71.

57 Ibidem, s. 106-107, 123.

58 Pisma, T. IX, s. 148, 152-153 Pisał: „Polska może rozwiązać wielkie zagadnienia swego bytu, zarówno gospodarcze, jak i polityczne, tylko na jednej drodze, tylko przez wzmocnienie i decydujące wysunięcie na czoło naszego politycznego życia tych czynników, które łączą ludzi w jedną, mocnymi węzłami moralnymi związaną całość społeczną, które pogłębiają w człowieku przywiązanie do dóbr duchowych, moralnych i każą mu je stawiać wyżej ponad materialne, które są potężnym hamulcem dla pierwotnego egoizmu jednostki. Tymi czynnikami są religia, katolicyzm i poczucie narodowe, przywiązanie do ojczyzny polskiej. Tym czynnikom nie daliśmy dotychczas w naszym życiu politycznym roli, jaka im się należy ze względu na ich doniosłe znaczenie w rozwiązywaniu najważniejszych i najtrudniejszych zagadnień społecznych i politycznych i ze względu na ich siłę w naszym społeczeństwie. Właściwie trzeba sobie powiedzieć, że nie umiały sobie one wziąć dotychczas tej roli, jaka im się należy”, (ibidem, s. 152-153). 
narodu: „Naród polski. [...] musi on mieć odpowiednią organizację. Tej organizacji dotychczas nie wytworzył z szeregu przyczyn, wśród których przede wszystkim wskazać trzeba: nałóg ślepego naśladownictwa wzorów obcych, bez ścisłej oceny ich wartości, a w związku z tym uleganie wpływom obcym, często wprost wrogim; reakcja na wiekową niewolę w dążeniu do zbytniej wolności, przy której żadna zdrowa organizacja nie jest możliwa; nieumiejętność odróżnienia w sprawach publicznych rzeczy ważnych od podrzędnych, zagadnień dzisiejszych, palących od tego, co jest muzyką przyszłości i to taką, co do której nie wiadomo, czy kiedykolwiek będzie zagrana; atmosfera rewolucyjna, wśród której państwo zostało odbudowane i która odwróciła uwagę ludzi od najważniejszych zagadnień państwowego bytu; powojenny stan przytępienia i obniżenia moralnego, stwierdzony w całej Europie; wreszcie surowość kulturalna i polityczna większości żywiołów, tworzących nasze nowe życie polityczne" ${ }^{\text {"9 }}$.

W jego ujęciu „organizacja narodu [...] to nie tylko skupienie, ujęcie we właściwe kadry wszystkich świadomych siebie sił narodu, pociągnięcie do służby wspólnej sprawie wszystkich energii i zdolności, wszystkich gotowości do ofiar i poświęceń dla Ojczyzny; to także, i to przede wszystkim, nieustanna praca nad wzmocnieniem wiekowych podstaw religijnych, moralnych i cywilizacyjnych narodowego bytu, to codzienna walka ze wszystkim, co te podstawy rozkłada, to wytężona twórczość myśli i twórcze działanie w życiu, skierowane ku uczynieniu narodu siłą jak największą, jak najbardziej przystosowaną do warunków dzisiejszego bytu, do dzisiejszej pracy i walki, by nie tylko trwał, ale szedł naprzód do swych przeznaczeń, szedł jako istota świadoma, myśląca, widząca jasno swe cele i umiejąca wybierać prowadzące do nich drogi”. Dodawał, że jednomyślność narodu prowadziłaby do stagnacji, martwoty a „dojrzałość polityczna kraju polega nie na ujednostajnieniu myśli, jeno na zrozumieniu, że nie każda myśl ma prawo wyodrębniać się w osobną organizację" 60 .

Widział korzyści i zalety zorganizowanego narodu: „Tylko zorganizowany naród może wysunąć na czoło życia kraju te wartości, które stanowią podstawę bytu społecznego i postępu cywilizacji, które ludzi podnoszą moralnie i wskazują im coś wyższego ponad dobra materialne, czynniki, które ich wiążą w jedną całość społeczną i nakazują dobro całości stawiać ponad wszystko. Tylko zorganizowany naród może znaleźć w sobie siły do rozwiązywania wielkich zagadnień gospodarczych i politycznych doby dzisiejszej i zagadnień naszego w szczególności bytu państwowego. Tylko wreszcie zorganizowany naród może dziś wydać władzę w państwie,

\footnotetext{
59 Ibidem, s. 158-159.

60 Pisma, T. X, s. 66, 71-72.
} 
poczuwającą się do surowej odpowiedzialności za jego losy i za położenie jego ludności, może rozwiązać to najtrudniejsze dziś wszędzie zagadnienie rządu" ${ }^{\prime \prime 1}$.

Ostro pisał o elitach politycznych Polski, zarzucał im polityczny analfabetyzm, brak należytej kultury i ogłady politycznej, brak doświadczenia politycznego i uważał, że to należy szybko zmienićć ${ }^{62}$. W 1925 roku w jednym z listów do Stanisława Kozickiego pisał: „Trzeba trochę uczyć naszych polityków rozumienia więcej polityki światowej. Utknięcie nosem całkowicie w polityce europejskiej narażać nas będzie na ciągłe niespodzianki" ${ }^{63}$. Wskazywał również na niski poziom kultury politycznej społeczeństwa. Widział jedną „z najgłówniejszych przyczyn rozstroju naszego politycznego życia i słabości naszego państwa" w tym, że ordynacja wyborcza „obejmuje największą liczbę mieszkańców kraju”, a wedle Dmowskiego „[... jest pewnikiem, że im więcej jest głosujących, tym większą przewagę mają ludzie głupi, politycznie ciemni”. Tłumaczył te zjawiska następująco: „[...] należymy do narodów, posiadających względnie niską kulturę polityczną i słabe wyszkolenie w sztuce rządzenia się samodzielnie. W tym wszakże względzie poszczególne ziemie polskie ogromnie się między sobą różnią. W ogóle w dzisiejszej Europie jesteśmy państwem, które w granicach swoich przedstawia największe różnice nie tylko stopnia, ale i charakteru cywilizacji. Nasze ziemie wschodnie pozostają co najmniej o dwa stulecia w tyle poza zachodnimi, i bardzo niebezpiecznym w naszym organizmie państwowym jest fakt, że konstytucja odpowiednia dla jednych ziem, będącą dla nich odpowiedzią na wymagania życia, dla innych jest za postępowa, przedwczesna w takiej mierze, że ich mieszkańcy nie są zdolni jej zrozumieć. Przy takim stanie rzeczy koniecznością jest, ażeby ziemie wyższe swą cywilizacją, swą pracą i wytwórczością, swym wyszkoleniem prawnym i politycznym, miały znacznie większy wpływ na państwo, aniżeli ziemie, pozostające w tyle. Konieczne jest to nie tylko ze względu na pomyślny bieg spraw państwowych, ale także dla przyśpieszenia rozwoju politycznego narodu jako całości, który będzie zapewniony wtedy, gdy jego część wyższa cywilizacyjnie, przy swej przewadze, będzie wychowywała resztę. Jeżeli przeciwnie, mniej cywilizowane ziemie będą miały przewagę i swym wpływem będą zatapiały wpływ ziem wyż-

61 Pisma, T. IX, s. 159-160.

62 R. Dmowski, Pisma, T. X, s. 216. „[...] jesteśmy jednym z krajów posiadających najniższą kulturę polityczną w Europie, ponieważ historia ostatnich kilku pokoleń sprawiła, że w rządzeniu się mamy mniej doświadczenia, niż narody niższe od nas cywilizacyjnie. [...] mająca poczucie swego obowiązku względem całości i wiedząca, jaki temu poczuciu należy dać wyraz mniejszość [...] należymy do narodów, posiadających najwięcej politycznych analfabetów”.

63 M. Kułakowski [Józef Zieliński], Roman Dmowski w świetle listów i wspomnień, T. II, Londyn 1972, s. 241. 
szych, naród będzie się cofał i poziom polityczny państwa będzie się obniżał”. Sugerował rozwiązanie tego problemu: „Dlatego jednym z ważniejszych postulatów w zakresie prawa wyborczego u nas jest, ażeby przy tworzeniu okręgów wyborczych uwzględniono cyfry, wyrażające nie tylko liczbę mieszkańców, ale także poziom oświaty i cywilizacji, poziom kultury gospodarczej, wytwórczości, siłę podatkową danej ziemi itd. Jest to nie tylko potrzebne dla pomyślnego rozwoju państwa, ale i słuszne i sprawiedliwe" ${ }^{64}$. Dmowski miał rację co do nierównomiernego rozwoju ziem polskich, do olbrzymich różnic cywilizacyjnych, ale czy jego pomysł nie miał na celu ograniczenia praw wyborczych mniejszości narodowych (Żydzi, Ukraińcy, Białorusini) w Polsce, które zresztą przeważały w wielu powiatach, miastach i wsiach zacofanego wschodu kraju ? W publicystyce przywódcy endecji dużo miejsca zajmują rzeczywiście Żydzi i kwestia żydowska na świecie, a nade wszystko w Polsce. Z czasem, zwłaszcza w latach 30., Dmowski miał obsesję na punkcie Żydów, zaś jego sądy miał charakter na wskroś antysemicki: „Ogólnie mówiąc, to jest jasne, że chcąc zapewnić przyszłość Polski, trzeba usilnie i konsekwentnie dążyć do tego, żeby Żydów w naszym kraju było coraz mniej, żeby nie rośli, jak dotychczas w siłę naszym kosztem. Podstawą ich siły jest opanowanie handlu w Polsce, a w części znacznej i rzemiosła, zażydzenie naszych miast i miasteczek. Polacy muszą sami wziąć w ręce swój handel, oczyścić z Żydów swe rzemiosła, do tego zaś trzeba, żeby nie popierali handlu żydowskiego, żeby każdy Polak uznał za swój obowiązek nie kupować niczego u Żydów. Tylko tą drogą możemy dojść do stworzenia silnego handlu polskiego i do tego, żeby naród polski został na powrót panem miast swoich. Naród, w którego miastach panoszy się obcy żywioł, nie jest naprawdę panem swego kraju i nie może być pewien przyszłości swego państwa” ${ }^{65}$. Przeszkodę w budowaniu „zdrowego, silnego państwa” widział w „potwornie wielkim odsetku ludności żydowskiej w Polsce” stąd „pierwszym warunkiem zbudowania mocnego, opartego na zdrowym i silnym społeczeństwie, zdolnego do odgrywania samoistnej roli w świecie państwa polskiego jest usunięcie tej trudności z naszego życia. Dopóki Polska będzie miała to smutne pierwszeństwo w świecie, że jest krajem najbardziej żydowskim, dopóty nie ma mowy o tym, żeby mogła ona być państwem zdrowo rozwijającym się na wewnątrz i zdolnym śmiało patrzeć w oczy niebezpieczeństwom zewnętrznym"66.

Można wskazać na jeszcze dwa, specyficzne, postulaty modernizacyjne Dmowskiego, które zawarł w pracy Polityka polska i odbudowanie państwa (1925), a mia-

\footnotetext{
64 Pisma, T. X, s. 216, 220-221.

65 Ibidem, s. 182.

66 Pisma, T. VIII, s. 440.
} 
nowicie napisał, że polscy dyplomaci, polska służba dyplomatyczna niepodległej Polski powinna wzorować się na rosyjskich (carskich) dyplomatach z czasów I wojny światowej (dobre maniery, duża inteligencja, opanowanie języka francuskiego ${ }^{67}$. Drugi to „oczyszczenie” polskiej służby urzędniczej z „Austriaków”, tj. ludzi będących przed 1918 K.u.K. Beamten, którzy zdaniem Dmowskiego nie byli prawdziwymi Polakami, przynosili ze sobą cynizm, obłudę i brak prawdziwego przywiązania do Polski ${ }^{68}$. Wiele uwagi zaprzątały Dmowskiego kwestie reformy i modernizacji ustroju państwa polskiego: w roku 1925 pisał dosadnie: „Dziś głównym nieszczęściem jest zły ustrój polityczny państwa. Ten ustrój trzeba przede wszystkim zmienić" ${ }^{69}$. Dmowski odwoływał się zarówno do wzorów zachodnich: „przywiązanie do tradycji cywilizacyjnych kraju, poczucie prawa i przywiązanie do praworządności, dyscyplinę religijną i moralną. Tylko to siła może wydać twórczość dziejową Polski i zapewnić jej trwałe podstawy bytu. Wszystko, co się jej przeciwstawia, prowadzić może jedynie do zniszczenia pomyślnie odzyskanego państwa" (rok 1926), jak i do wzorów faszyzmu włoskiego: ówczesny ustrój polityczny Polski zdaniem Dmowskiego „wykazuje dzisiaj swą niewypłacalność. Wszędzie już stwierdza się jego fatalne skutki, ale próbę poważną w kierunku jego przekształcenia zrobiono dotychczas tylko w jednym kraju, we Włoszech”. Z uznaniem spoglądał na faszyzm, który ,jest wytworem szczególnego położenia narodu włoskiego i włoskiego charakteru narodowego. Dlatego faszyzm w innym kraju jest niemożliwy. W tym wszakże, czego już dokonał, są rzeczy, mające znaczenie ogólniejsze, są zdobycze myśli politycznej, które nie pozostaną jedynie włoskimi. Naczelne miejsce tu zajmuje zasada, że dzisiejsza doba obok państwa, będącego organizacją ludności na danym obszarze, wymaga organizacji narodu, związania do wspólnego czynu tych wszystkich ludzi, którzy dobro ojczyzny, jej potęgę i jej przyszłość stawiają w tym życiu ponad wszystko, którzy poczuwają się do obowiązku służenia jej w każdej chwili i gotowi są dla niej do ofiar i poświęceń”70.

Ważnym krokiem do zmodernizowania ustroju politycznego państwa polskiego była zmiana Konstytucji Marcowej, gdyż zdaniem Dmowskiego była zła, a poza tym nie przestrzegano jej i stała się fikcją. Pomysł zmiany ustawy zasadniczej wysuwało naówczas wiele ugrupowań i środowisk politycznych. Postulował ograniczenie dominacji Sejmu (sejmowładztwa) w systemie władzy, a także wzmocnienie władzy prezydenta RP w celu stabilizacji władzy rządu ${ }^{71}$. Rozważał

67 Pisma, T. V., s. 257.

68 Ibidem, s. 302-303.

69 Pisma, T. X, s. 15.

70 Ibidem, s. 91, 132.

71 Ibidem, s. 213-214. 
także kwestię podniesienia wieku osób wchodzących do Senatu w celu uczynienia tej izby jeszcze bardziej konserwatywną, postulował zmianę ordynacji wyborczej i zniesienie proporcjonalności, czyli koniec z małymi partiami i rozdrobnieniem Sejmu. Modernizację ustroju reprezentacyjnego widział też w oddaniu prawa głosu głowom rodziny: „W ustroju reprezentacyjnym należy się przedstawicielstwo rodzinie, i najsilniejszy, najzdrowszy byłby system reprezentacyjny, w którym by przy wyborach przedstawicielstwa głosowała rodzina w osobie jej głowy, to znaczy ojca rodziny, lub tam, gdzie tylko jedno z rodziców żyje - ojca lub matki. Żadna krzywda państwu by się nie stała, gdyby jednostkom obojga płci, nie posiadającym rodzin, pozostawiono tylko bierne prawo wyborcze"72. Uważał, że polskie państwo może być jedynie silne jako państwo narodowe: „Do Polaków należy prowadzić do państwo i nim rządzić. Dopuszczenie żywiołów niepolskich do wpływu na rządy musi państwo osłabiać, a gdyby te wpływy nabrały znaczniejszej siły, musiałoby się to skończyć upadkiem państwa. Państwo nasze może być silnym, może istnieć w ogóle jedynie jako państwo narodowe polskie"73.

W 1933 roku podkreślał, że ratunkiem dla Polski jest odejście od rządów parlamentarnych (1918-1926) i przyjście rewolucji narodowej: „Rewolucja narodowa, burząca rządy demokracji w miarę swego szerzenia się w Europie, niesie Polsce ratunek. Zwyciężyła ona dotychczas tylko w dwóch krajach, we Włoszech i w Niemczech, ale wszystko przemawia za tym, że jej zwycięstwo w całej Europie jest nieuchronne. Nastąpi ono przede wszystkim w tych krajach, które przez krótszy okres były wystawione na rozkładowe działanie rządów parlamentarnych i których ludność odznacza się skutkiem tego mocniejszymi instynktami narodowymi. Następnie będą musiały pójść za nimi i kraje, w których rządy demokracji najbardziej się utrwaliły, w których masoneria jest najsilniejsza. Będą musiały to zrobić ze względu na politykę zewnętrzną, jeżeli wewnętrzne względy nie wystarczą. [...] Zwycięstwo tedy rewolucji narodowej jest bodaj nieuniknione w całej Europie. To zaś otwiera przed nami widoki na możność zorganizowania naszego państwa zgodnie z potrzebami i celami narodu polskiego"74.

Publicystyka Dmowskiego w kwestiach ustrojowych (podobnie jak w wielu innych kwestiach) ma piętno wybitnie nacjonalistyczne - prócz nacjonalistycznej retoryki można się doszukać także jakiegoś mętnego ekskluzywizmu: „W wysuwającym się dziś coraz silniej na porządek dzienny w naszym państwie zagadnieniu ustrojowym obóz narodowy polski ma więcej do powiedzenia, niż jakikolwiek

\footnotetext{
72 Ibidem, s. 219-222.

73 Ibidem, s. 178.

74 Pisma, T. VIII, s. 399-400.
} 
inny odłam opinii. [...] Dąży on do tego, żeby upadający w Europie parlamentaryzm do Polski nie wrócił, ale wie dobrze, że zastąpić go może tylko ustrój mocno, konsekwentnie oparty na podstawie narodowej. Ten nowy ustrój może dać Polsce tylko nowoczesna myśl narodowa, rozwinięta wszechstronnie w jeden konsekwentny, integralny system. I ten ustrój może się oprzeć jedynie na narodzie polskim jako twórcy państwa polskiego, jego właścicielu i gospodarzu, odpowiedzialnym za jego losy. Wszelkie próby, odrzucające podstawę narodową, mogą prowadzić tylko do rozstroju"75.

Dmowski uważał, że zmiana postaw i mentalności społeczeństwa w kierunku osiągnięcia dostatecznie silnego poczucia prawa i przywiązania do prawa (jak zdolność do obrony prawa i przeciwstawienie się wszelkiej samowoli) doprowadzi do faktycznego istnienia praworządnego państwa polskiego, a „do tego zaś możemy dojść tylko przez zorganizowanie sił narodu wszystkiego, co w nim jest istotnie polskim, a więc zachodnim, na zasadach rzymskich wyrosłym, co chce mieć Polskę wielką i potężną, i co rozumie, jaka droga do niej prowadzi”"76. Uzależniał siłę państwa od siły społeczeństwa, nie tylko na płaszczyźnie materialnej, lecz przede wszystkim w sferze moralnej. Głosił hasło wzmocnienia państwa polskiego przez zaoszczędzenie konfliktów, niewywoływanie konfliktów czy wstrząsów, spotęgowanie zainteresowania sprawami bezpieczeństwa i obrony państwa, uświadamianie narodowo jednostek mniej wyrobionych tudzież wprzęgnięcie ich do służby Polsce ${ }^{77}$. Zdaniem autora Myśli nowoczesnego Polaka demokratyzacja po 1918 sięgnęła w Polsce ostatecznych granic, ale „można [...] kulturalnie i umysłowo podnosić lud, ażeby umiał z praw swoich korzystać z pożytkiem dla państwa i dla siebie, ażeby prawa jego, skutkiem jego nieprzygotowania, nie były tak jak dziś przeważnie martwą literą, nie pozostawały właściwie prawami tych, którzy się wyspecjalizowali w wyzyskiwaniu jego łatwowierności"78.

Dmowski wysuwał także hasła zmiany mentalności w celu unowocześnienia Polski. Postulował większą aktywność ludności województw poznańskiego i pomorskiego w życiu Polski, ich większe otwarcie na Polskę (pisane w 1925 roku) ${ }^{79}$. Postulował ponadto potrzebę jak największej liczby ludzi myślących o Polsce, dbających o nią, o całość Polski, ale również ludzi pracowitych, niebojących się ciężkiej pracy oraz rywalizacji i konkurowania z innymi - tu widział wielkie braki, krytykował złe nawyki polskie, widział brak umiejętności współzawodnictwa:

\footnotetext{
75 Ibidem, s. 444.

76 Pisma, T. X, s. 147-148.

77 Ibidem, s. 230, 243-244.

78 Ibidem, s. 245.

79 Pisma, T. IX, s. 271.
} 
„W konkurencji światowej wytrzymają tylko te narody, które przede wszystkim umieją pracować, to znaczy dostatecznie dużo pracują i umiejętnie pracują, tj. nie robią rzeczy niepotrzebnych, tylko potrzebne. I tu trzeba powiedzieć, że my do współzawodnictwa jesteśmy bardzo słabo na tym punkcie przygotowani. Polak szczególnym miłośnikiem pracy nigdy nie był. [...] na ogół szczególnymi zwolennikami pracy nie jesteśmy. A już, jak się Polska odbudowała, to powiadano sobie: no, przecież teraz na to nam Polskę odbudowano, żebyśmy mogli sobie odpocząć. [...] Jeśli chcemy, żebyśmy w tym okresie, w którym Europa schodzi na dziady, nie zeszli już na najgorsze dziady, bo należymy do najuboższych narodów w Europie, żebyśmy nie zostali już zupełnie żebrakami i bankrutami, to trzeba zwiększyć u nas ilość pracy i zrobić ją bardziej skuteczną. Trzeba uczyć ludzi, jak pracować, żeby jak najwięcej owoców z niej było" ${ }^{\prime 0}$. Wysuną inny postulat modernizacyjny - zresztą słuszny - należało jego zdaniem zmienić podejście społeczeństwa do państwa: „Trzeba zrozumieć, że nad wielu stronami życia i położenia narodu państwo czuwać nie może, nad wielu zaś nasze w szczególności państwo czuwać dziś nie jest zdolne, że są wreszcie takie strony, nad którymi czuwa źle, ze szkodą lub niebezpieczeństwem dla narodu. Tu musi czuwać i działać zorganizowany naród" ${ }^{81}$. Postulował również uświadamianie ludności o problemach gospodarczych i społecznych Polski: „Wielką kwestię naszego bytu, kwestię położenia gospodarczego kraju i dróg ratunku trzeba dziś postawić przed całym krajem, przed wszystkimi warstwami jego ludności. Trzeba przez należytą organizację umożliwić krajowi pokazanie, że w Polsce znajduje się dostateczna ilość ludzi którym droga jest przyszłość Ojczyzny i którzy nie są zdolni obojętnie patrzeć, jak ich rodacy giną z głodu" ${ }^{\prime 2}$.

Dmowski z drobnomieszczańskiego domu rodzinnego wyniósł surowe spojrzenie na obyczajowość - w roku 1927 pisał o upadku obyczajów i jego destrukcyjnym wpływie na życie polskiego społeczeństwa i apelował o przeciwdziałanie w celu „udoskonalenia” polskiego narodu: „Dusza ludzka nie podnosi się na wyższy poziom moralny, nie uszlachetnia się, ale podleje w atmosferze rozpasania obyczajowego i publicznego bezwstydu. [...] jeżeli chcemy z narodu zrobić potęgę, silnie go zorganizować, uczynić go zdolnym do lepszego czucia i myślenia i do ofiarnego czynu, musimy wypowiedzieć bezwzględną walkę temu rozkładowi obyczajów, jaki dziś, zwłaszcza w powojennym okresie szerzy się przez literaturę, prasę, teatry i inne widowiska, dancingi itp." ${ }^{83}$. Warto dodać, że wielu antysemitów polskich za pewne obiektywnie zachodzące procesy przemian w obyczajowo-

\footnotetext{
80 Ibidem, s. 25-27.

81 Pisma, T. X, s. 67.

82 Pisma, T. IX, s. 225-226.

83 Pisma, T. X, s. 133.
} 
ści i stosunkach międzyludzkich winiło osoby narodowości żydowskiej. Uważał, że należy rozwijać u ludzi (zwłaszcza z niższych warstw społecznych) świadomość narodową, poczucie obowiązku narodowego i odpowiedzialności za losy Polski; wskazywał, że przywiązanie do Ojczyzny (bezinteresowne) może stanowić kapitał Polaków na przyszłość ${ }^{84}$. Podkreślał, że w Polsce za mało jest dojrzałości moralnej, za mało poczucia odpowiedzialności, za mało ludzi z charakterem, posiadających własne zasady i sumienie, a za dużo pychy, próżności, ciemnoty politycznej ${ }^{85}$. Powtarzał, że ważne dla społeczeństwa polskiego musi być nie naśladownictwo (obcych wzorów), lecz własna twórczość, kreatywność („Narody wszakże budują swe losy, swą wielkość nie naśladownictwem, jeno twórczością") ${ }^{86}$.

W innym miejscu swych pism podkreślał rolę myślenia nie tylko o dniu dzisiejszym, ale co ważniejsze o dniu jutrzejszym oraz po raz kolejny samodzielność myślenia. Tak definiował zadania dla Polaków: „Pierwsze - to myśleć nie tylko o dniu dzisiejszym, o jego brakach i niedomaganiach, o jego potrzebach i pragnieniach, ale i o jutrze: walczyć o bliższe i dalsze jutro, pracować nie tylko dla siebie, ale i dla tych, co po nas przyjdą. Drugie - to samodzielnie myśleć po polsku i niezależnie po polsku działać. Nie mogą oni kreślić sobie dróg postępowania pod rozkazami, czy nawet pod natchnieniami obcymi, w najniewinniejszym zaś wypadku, małpować bezmyślnie tego, co gdzie indziej ludzie robią. Czerpać muszą swój program z rzeczywistości polskiej, z uczciwego poznania położenia kraju i grożących mu niebezpieczeństw, ze zrozumienia swego narodu, jego charakteru, sił i zdolności. Polityka narodowa nie może nic gotowego zapożyczać - musi sama sobie wszystko tworzyć" "87. Dmowski w 1932 roku skonstatował, że trzeba się odciąć od Europy w sferze myślenia („Pierwszym zaś warunkiem do tego, żebyśmy po właściwej drodze poszli, jest odcięcie się od dzisiejszej Europy pod jednym nade wszystko względem. Gdy ona prawie cała żyje pod panowaniem dnia dzisiejszego, po wczorajszemu rozumianego, niezdolna do spojrzenia w przyszłość - my wyzwólmy się nieco z tej jałowej szarpaniny dzisiejszej, zacznijmy myśleć o jutrze i pracować dla lepszego jutra”) ${ }^{88}$.

Podkreślał potrzebę pojawienia się nowych pokoleń: „Trzeba nowych pokoleń, które by nie tylko rozumiały, co to jest własne państwo oraz wypływające z niego obowiązki i odpowiedzialności, ale które by sobie zdawały sprawę z dzisiejszej wielkiej doby historycznej, z przewrotu odbywającego się w świecie i w położeniu

\footnotetext{
84 Pisma, T. IX, s. 155, 145-146.

85 Pisma, T. X, s. 195.

86 Pisma, T. IX, s. 157.

87 Pisma, T. X, s. 191.

88 Pisma, T. VIII, s. 34.
} 
Polski; trzeba nowego gatunku ludzi, mocnych, mężnych charakterów i umysłów, zdolnych do wielkich wysiłków i w pracy nad sobą, i w walce z przeciwnościami i przeszkodami, którzy nie czekają, że bez ich czynów i poświęceń los im wszystko przyniesie. [...] Wielkie, otwierające się przed nami zadania wymagają ludzi nietandetnych, wychowanych nie do łatwego życia i łatwych zdobyczy ubiegłego okresu, i umysłów tęższych i większych charakterów" 99.

Jako bystry obserwator polityki po przewrocie majowym Dmowski wysunął także dwa skromne postulaty modernizacyjne odnośnie wojska: odpolitycznienia wojska oraz wprowadzenia jednolitego kodeksu wojskowego ${ }^{90}$.

Po przyjeździe do Polski w maju 1920 roku bacznie przyglądał się budowie odrodzonej Polski. Warto zanalizować jego opinie na temat położenia i stanu Polski w okresie międzywojennym. Dmowski pisał i dobrze i źle o Polsce międzywojennej. Zawsze chciał Polski silniej, niezależnej gospodarczo i politycznie wskazywał na wielkie znaczenie dostępu Polski do morza, posiadania wysoko rozwiniętych ziem dawnego zaboru pruskiego jak Poznańskie czy Pomorskie oraz bogatego w węgiel, rudy, kopalnie i huty Górnego Śląska ${ }^{11}$. W pismach politycznych przywódcy endecji narracja „optymistyczna” o Polsce splatała się z narracją „pesymistyczną”. Można trafić na pozytywne opinie o Polsce jak ta z 1925: „[...] Polska żyje, porządek w niej jest jaki jest, ludzie, choć narzekają, z głodu nie umierają, i w całym szeregu dziedzin życia widać szybki postęp, pochód ku lepszej przyszłości. Niewątpliwie, są w naszym życiu państwowym wielkie trudności i wielkie niebezpieczeństwa, ale któreż państwo na świecie ich nie ma ?"92.

Warto przytoczyć inną wypowiedź z tego samego roku: „Polska XX wieku już nie jest tym krajem z zabójczo uproszczoną budową społeczną, którego ludność składa się prawie wyłącznie z narodu szlacheckiego i z biernej masy poddanych chłopów, krajem zabitym deskami od świata, nie wiedzącym, nie rozumiejącym, co się naokoło niego dzieje, w którym nieliczna sfera, oświecona po europejsku i utrzymująca z Europą stosunki, więcej związana jest moralnie i umysłowo z zagranicą, niż z krajem. Nie jest to już owo społeczeństwo naiwne, żyjące urojeniami i złudzeniami, nie zdające sobie sprawy ze współczesnej rzeczywistości, z własnego położenia, dające sobie wmawiać najniedorzeczniejsze pojęcia i pomysły. Nie jest to wreszcie ów pozbawiony wewnętrznej organizacji naród, niezdolny do przeja-

\footnotetext{
89 Pisma, T. X, s. 6-7.

90 Ibidem, s. 64-66.

${ }^{91}$ Pisma, T. V: Polityka polska i odbudowanie państwa. Cz. I. Przed wojna. Wojna do r. 1917, Częstochowa 1937, s. 27, 29-30, 32, 168-169; Pisma, T. VI: Polityka polska i odbudowanie państwa. Druga połowa. Wojna od r. 1917. Pokój, Częstochowa 1937, s. 194; Pisma, T. IX, s. 225 i n.

${ }_{92}$ Pisma, T. V, s. 331.
} 
wiania swego instynktu samozachowawczego, któremu organizację przynoszono z zewnątrz i z zewnątrz wytykano d rogi działania. Jesteśmy dziś o wiele więcej, niż byliśmy jeszcze pięćdziesiąt lat temu, narodem. W ciągu tego ostatniego pięćdziesięciolecia świadomość narodowa w szerokich masach zrobiła olbrzymie postępy. Twarda walka o byt narodowy, a jednocześnie wytężona walka o byt gospodarczy, wydobyła już dużo uśpionej energii z narodu, nauczyła go mierzyć się z rzeczywistością, liczyć się z faktami, patrzeć prawdzie w oczy, wykształciła niemały już realizm w sposobie myślenia. Przemiany polityczne w państwach, do których należeliśmy, wciągnęły społeczeństwo w życie polityczne: $\mathrm{w}$ ścieraniu się z zagadnieniami tego życia polityka przestawała być funkcją oderwaną, poezją, literaturą, zaczęto rozumieć jej związek z życiem. Udział w parlamentach pociągnął za sobą organizację społeczeństwa w stronnictwach politycznych. Na tym tle kształciła się samoistna myśl polityczna, krytyczna ocena położenia narodu, krytycyzm w stosunku do haseł i programów, wytwarzała się zdolność do tworzenia planu działania i do zorganizowanego czynu. W tych słowach maluję nie proces, który się zakończył, ale który odbywał się szybko, który, zależnie od warunków, w różnych częściach Polski różne zrobił postępy, który najdalej zaszedł w zaborze pruskim, gdy na przeciwnym krańcu Polski, w Krajach Zabranych, dopiero początkował [...] Skutkiem postępów tego procesu naród polski coraz zdatniejszym się stawał do nowoczesnego życia, do pracy, której to życie wymaga, i do walki o własne dobro, którą ono narzuca" ${ }^{\prime 3}$.

W 1929 mówił o postępie, jaki zaszedł w Polsce w latach 1919-1929: „W jak wielu dziedzinach cywilizacyjnych i gospodarczych Polska szybko poszła naprzód w ciągu pierwszego dziesięciolecia swej niepodległości, najlepiej świadczy wystawa [chodzi o Powszechną Wystawę Krajową zorganizowaną w 1929 w Poznaniu WK]” ${ }^{4}$. Pozytywnie wypowiadał się o pracy Polaków: „Naród polski licznymi faktami zaświadcza o swojej jedności, sile i żywotności; jego praca cywilizacyjna i gospodarcza dźwiga szybko jego życie zbiorowe na wyższy poziom i pomnaża jego siły. Coraz więcej będzie on ważył w naszej części świata. W miarę dorastania nowych, niewyrosłych w niewoli pokoleń, coraz szybciej przezwyciężać on będzie trudności wewnętrzne: ustali on formy swego bytu i pójdzie szybkim krokiem do należnego mu stanowiska mocarstwowego. Wielkie, silne państwo polskie potrzebne jest nie tylko nam do naszego rozwoju narodowego, do urzeczywistnienia naszych celów i spełnienia naszych zadań. Niemniej jest ono potrzebne do utrwalenia pokoju, a z nim warunków wielkiej pracy cywilizacyjnej całej Euro-

\footnotetext{
93 Pisma, T. VI, s. 217-219.

94 Pisma, T. IX, s. 10.
} 
py” ${ }^{\prime 9}$. Dostrzegł wzrost świadomości ekonomicznej polskiej ludności: „Polska dziś w ustroju swego handlu szybko zbliża się do zachodniej Europy. Coraz mniej jest u nas ludzi, nie wiedzących, dokąd się zwrócić, gdy mają coś do kupienia, czy do sprzedania, coraz mniej potrzebujących drobnego pośrednika, faktora. Dlatego to dziś wśród ludności żydowskiej naszych miasteczek szybko zapanowuje coraz większa nędza" ${ }^{\prime \prime}$.

W 1932 roku, w czasie trwania w Polsce kryzysu gospodarczego, Dmowski chyba zbyt optymistycznie i mało realistycznie spoglądał na Polskę: „,...] wytwórczość rolnicza, przy obecnym stanie kultury rolnej i przy jej postępie w przyszłości, tak się przedstawia, iż nie budzi obaw, ażeby mogła stać się niewystarczająca dla kraju, nawet przy bardzo szybkim wzroście zaludnienia. Posiada ona surowce dla przemysłu w większej pełni, niż jakikolwiek inny kraj europejski: jedyne w Europie posiada oba najważniejsze - węgiel i naftę, ostatnią, co prawda, w niewielkiej ilości, wystarczającej wszakże dla niej przy dobrej gospodarce. Jej kultura przemysłowa znajduje się na poziomie, na którym z niewielkimi wyjątkami mogłaby ona swe potrzeby przemysłowe sama zaspokoić. Dziś w różnych dziedzinach nie wytrzymuje współzawodnictwa cen. Ta wszakże przeszkoda z upadkiem handlu międzynarodowego będzie bodaj coraz łatwiejsza do usunięcia. Obecny tedy przewrót nie jest dla Polski nieszczęściem. Przeciwnie, otwiera on przed nią widoki na pomyślniejsze znacznie położenie, niż przed wielu innymi krajami" "97.

W życiu Polski Odrodzonej oprócz dobrych stron widział wiele stron negatywnych, wiele problemów. Pisał o braku doświadczenia i wadach przy tworzeniu Polski w 1918 roku, o braku dużych kapitałów w Polsce, o „karykaturalnym kapitalizmie" w Polsce (kapitalizm bez kapitałów), o wzroście liczby młodych absolwentów pozostających bez pracy, o Polsce jako kraju rolniczym, zacofanym ${ }^{98}$. Pisał o chaosie w Polsce, o wprowadzeniu systemu parlamentarnego jako złej, fatalnej dla Polski decyzji (brak doświadczenia i treningu demokratycznego, analfabetyzm), o kłopotach wsi, zacofaniu wsi i mas wiejskich (słaba świadomość politycz-

95 Ibidem, s. 13. Najogólniej rzecz ujmując nie tylko Roman Dmowski, lecz także Józef Piłsudski oraz wielu innych polityków głosiło hasło Polski jako silnego państwa tj. państwa, które byłoby podmiotem polityki międzynarodowej, a nie jej przedmiotem czy też „klientem” wielkich mocarstw. Często łączono tę myśl z projektem Polski jako „mocarstwa regionalnego”, tj. regionalnego lidera w Europie Środkowo-Wschodniej; por. M. Kornat, „Polska jest mocarstwem” - czyli z dziejów polskiej kultury politycznej w XX wieku, [w:] idem, Polityka równowagi 1934-1939. Polska między Wschodem a Zachodem, Kraków 2007, s. 68-71, 110-122.

${ }_{96}$ Pisma, T. VII, s. 295.

97 Pisma, T. VIII, s. 32.

98 Pisma, T. IX, s. 207-209, 265, 303. 
na i narodowa, mała wiedza o świecie) etc.99. W sposób dobitny i wyraźny łączył złą sytuację, położenie Polski z obecnością i działaniem Żydów w Polsce - wskazywał na zły wpływ Żydów polskich na wszystko „co polskie i chrześcijańskie” (sic!), wpływ Żydów na masonerię! ${ }^{100}$.

Zacofanie Polski (pierwotne, rodzime barbarzyństwo) wiązał z „młodszością” cywilizacyjną Polski w stosunku do narodów zachodnich, z mniejszym ukształtowaniem przez cywilizację rzymską, złymi wpływami Wschodu wśród warstw oświeconych w Polsce oraz z brakiem religijności (Kościół katolicki jako „potężny wychowawca w duchu zachodnim” ${ }^{101}$. Motyw „wschodni” powrócił w innym tekście - Dmowski zarzucał polskim elitom politycznym „ducha wschodniego” (choć posiadali zalety i zasługi, to mieli „osłabione pojęcia europejskie”, „zachwiane poczucie prawa”). Przewrót majowy i okres po przewrocie, rządy sanacji to wedle Dmowskiego „okres najsilniejszego wezbrania fali wschodniej”102. W tej kwestii autor Myśli nowoczesnego Polaka był konsekwentnym okcydentalistą, czyli zwolennikiem oparcia cywilizacyjnych podstaw Polski na wzorcach zachodnich.

Określał Polskę jako państwo pogranicza, położone między Zachodem a Wschodem, gdzie krzyżowały się wpływy rozwiniętej cywilizacji zachodniej z zacofaną, „barbarzyńską” cywilizacją wschodnią: „Polska, która ciągle jeszcze pozostaje na granicy między cywilizacją a barbarzyństwem" ${ }^{103}$. Wielokrotnie o tym pisał - przykładowo o zacofaniu Polski w sferze praworządności: „Prawo-

99 Pisma, T. VIII, s. 397-398, 411, 418-419.

100 Pisma, T. X, s. 181-182.

101 Ibidem, s. 88-89.

102 Ibidem, s. 90. Jego zdaniem życie polityczne w odrodzonej Polsce to arena walki, starcia „wrodzonych już, utrwalonych przez wieki zachodnich, europejskich skłonności dążeń narodu z duchem wschodnim, duchem bezprawia i gwałtu, oraz z wydobywanym przezeń na widownię polityczną rodzimym barbarzyństwem" (ibidem, s. 89). W 1930 tak komentował życie polityczne: „Nasze wewnętrzne życie polityczne przedstawia obraz smutny, obraz w ogromnej mierze barbarzyństwa, głupoty i braku charakteru”, (Pisma, T. VII, s. 277). Dla Dmowskiego „uosobieniem” zacofanego Wschodu była nie tylko po 1918, ale i przed 1918 rokiem Rosja, której szczerze nie cierpiał - już w cyklu artykułów z 1905 pod tytułem „Obecny stan Rosji w perspektywie historycznej” - Dmowski okazał w nich pogardę czy wręcz nienawiść do Rosji, patrzył na ten kraj przez pryzmat „azjatyckości”, tj. jej wielkiego zacofania (R. Wapiński, Narodowa Demokracja 1893-1939..., s. 93). Uważał Rosję i Rosjan za państwo i ludzi nienależących do kultury Zachodu (cywilizacji rzymskiej) - Polska była ostatnim krajem w Europie, później na Wschód już inna cywilizacja (azjatycka) (K. Kawalec, Roman Dmowski..., s. 280). Wypada przytoczyć pewien passus z listu Dmowskiego do Ignacego Paderewskiego z 1917 roku o współpracy Dmowskiego z Rosją: „Jeżeli jest nagroda w życiu przyszłym za dobre czyny, to fraternizowanie z bydłem, do którego nikt większego wstrętu ode mnie nie miał, będzie mi policzone jako największe poświęcenie mego życia, poświęcenie nie bez pożytku” (M. Kułakowski [Józef Zieliński], op. cit., s. 82).

103 Pisma, T. X, s. 198. 
rządność państwowa zależy przede wszystkim od poczucia prawa w społeczeństwie. Pod tym zaś względem kraj nasz pozostaje daleko w tyle poza krajami zachodniej Europy. Sprawia to nasze położenie między Wschodem i Zachodem, sprawiają nasze losy dziejowe, skutkiem których postęp cywilizacji zachodniej, rzymskiej, który szedł od wieków dzięki pracy naszego Kościoła i naszych instytucji, nie miał ciągłości; [...] Wielkim cofnięciem się był okres naszej niewoli, głównie w ziemiach, które pozostawały pod panowaniem rosyjskim"104.

Dmowski wskazywał na powikłaną linię rozwoju i poziomu cywilizacyjnego Polski międzywojennej (z Zachodu na Wschód) oraz wielką rolę ziem zachodnich (tj. ziem byłego zaboru pruskiego) do odegrania w niepodległej Polsce: „[...] w miarę, jak posuwamy się w Polsce od granicy zachodniej ku wschodniej, coraz słabsze jest poczucie prawa, coraz większa skłonność do samowoli i coraz większa zdolność jej ulegania. I dlatego te ziemie zachodnie Polski mają szczególną w niej rolę, szczególne, bardzo doniosłe zadania i wypływające z nich obowiązki. Jest to rola najsilniejszego węzła, łączącego nas z cywilizacją zachodnią i przez to zapewniającego Polsce przyszłość państwa europejskiego, państwa opartego na prawie, a tym samym silnego; jest to zadanie walki o prawne podstawy naszego życia państwowego i obowiązek zwycięstwa przez oddziaływanie na słabsze pod względem poczucia prawnego ziemie naszego państwa"105.

Podkreślił, że „Polska w swych dzisiejszych granicach jest krajem z ogromną przewagą ludności typu zachodniego i ma wszelkie widoki stania się państwem zachodnim w całym swym ustroju, w całym życiu opartym na ścisłych i surowo przestrzeganych podstawach prawnych. Do tego wszakże może ona dojść tylko dużym, świadomym wysiłkiem żywiołów, które przedstawiają w niej cywilizację zachodnią̧"

104 Ibidem, s. 146. Pisał też: „w Polsce, państwie zbudowanym na kresach cywilizacji zachodniej, zawsze istniały i dziś istnieją wielkie różnice poziomu cywilizacji między ziemiami zachodnimi a wschodnimi”, (Pisma, T. IX, s. 9). Dmowski oceniając sytuację Polski w przededniu odzyskania niepodległości, mówił o „ścieraniu się” pierwiastków cywilizacji zachodniej i cywilizacji wschodniej w Polsce, w polskim społeczeństwie - „Grunt polski, na którym przez wieki Zachód czynił ciągłe zdobycze, posuwał się nieustannie ku wschodowi, pod wpływem panowania rosyjskiego stał się widownią zdobyczy Wschodu: powracająca fala wschodnia zaczęła się posuwać ku zachodowi. Społeczeństwo polskie we wschodniej części kraju weszło w dwudzieste stulecie, jako o wiele mniej zachodnie, niż było w poprzednich pokoleniach. Polska stała się o wiele mniej jednolita w swej psychice, w swych pojęciach moralnych i prawnych, w swej umysłowości politycznej. [...] tylko praca pokoleń w sprzyjających warunkach może przywrócić krajowi jedność cywilizacyjną, może uczynić Polskę krajem całkowicie zachodnim, a tym samym zapewnić jej mocne podstawy samoistnego bytu" (Pisma, T. X, s. 87).

105 Ibidem, s. 147.

106 Ibidem, s. 88. 
Rozważania Dmowskiego o położeniu Polski międzywojennej można zakończyć jego analizą zapóźnienia Polski, szybkością dokonujących się zmian społecznych w okresie odzyskania niepodległości i konsekwencjami tychże zmian: „Okres, któryś my przeżyli w niewoli, był okresem wielkich przeobrażeń w całym świecie naszej cywilizacji. W tych przeobrażeniach Polska została zapóźniona przez utratę niezawisłości, przez rozdarcie narodu i przez związanie głównego obszaru jej ziem z państwem, stojącym na znacznie niższym od niej poziomie cywilizacyjnym, o wiele mniej posuniętym w rozwoju społecznym, gospodarczym i politycznym. [...] Późno rozpoczęte przeobrażenia społeczne poszły naprzód w ostatnich latach kilkudziesięciu z szybkością, naruszającą równowagę społecznego życia, wytwarzającą wielkie niebezpieczeństwo społeczne, tym większe, że towarzyszyło im zapóźnienie mas w oświacie. Skutki tego nienormalnego, pozbawionego należytej ciągłości rozwoju dziś ponosimy i przez dłuższy jeszcze czas ponosić będziemy. Odbijają się one przede wszystkim w życiu politycznym narodu, czyniąc bardzo trudnym znalezienie odpowiedniej formy ustroju państwa. $Z$ tymi trudnościami można by się było porać skutecznie, gdyby warstwy przewodnie narodu, warstwy oświecone, w dzisiejszym pokoleniu posiadały dostateczną dojrzałość i wytrawność polityczną. Warstwy te wszakże, odsunięte pod obcym panowaniem od udziału w rządach, nie wykształciły się ani umysłowo, ani moralnie do spełnienia wielkich zadań, które na nie czekały. Brak im nie tylko umiejętności, ale i poczucia odpowiedzialności. Dopiero nowe pokolenia, wyrastające we własnym już państwie, rozwijają w sobie to poczucie, dochodzą do zrozumienia, że każdy oświecony, świadomy Polak jest odpowiedzialny za swe państwo, za rządy tego państwa, za błędy rządzących i za ich zbrodnie" ${ }^{107}$.

Rozważając kwestie idei modernizacyjnych w pisarstwie Romana Dmowskiego, nie można pominąć problemu wzorców modernizacyjnych i ewentualnego naśladowania. Wiadomo, że Dmowski był zafascynowany Wielką Brytanią (zwłaszcza Anglią), tamtejszym życiem społecznym, politycznym, obyczajami ${ }^{108}$. Chyba po konferencji pokojowej w Paryżu, gdzie rozczarował się wielce polityką brytyjską pod wodzą niezbyt bystrego Lloyda George’a, fascynacja Wielką Brytanią minęła. W latach 20. i 30., co widać z kart jego Pism, Dmowski był pod wrażeniem rozwoju państw azjatyckich (Japonia, Chiny) oraz państw europejskich,

107 Pisma, T. IX, s. 11-12.

108 Zdaniem K. Kawalca Dmowski przed, ale i po 1918 roku był pod silnym wrażeniem brytyjskich instytucji politycznych, które były oparte na systemie dwupartyjnym, który gwarantował stabilność systemu władzy (K. Kawalec, Spadkobiercy niepokornych..., s. 19); także R. Wapiński, Roman Dmowski, s. 87-88. Zresztą Dmowski marzył o istnieniu w Polsce jedynie dwóch, góra trzech stronnictw politycznych, por. Pisma, T. X, s. 70-71. 
lecz niedemokratycznych, mianowicie faszystowskich Włoch i nazistowskich Niemiec. Z czasem Dmowski „rozczarował się” i Włochami i Niemcami. Chyba nie miał jakiegoś wzorca czy wzorców modernizacyjnych - można mówić o wybiórczej, selektywnej recepcji idei zachodnich u Dmowskiego. Wydaje się (a poniższe cytaty powinno to potwierdzić), że stawiał on na „oryginalność, rodzimą „kreatywność”. Wielokrotnie, w różnych latach i w różnych tekstach krytykował „bezmyślne”, bezrefleksyjne polskie naśladowanie obcych wzorów. Uważał to za polską wadę. W 1914 roku napisał, że jedną z przyczyn upadku I Rzeczypospolitej było właśnie przenoszenie obcych wzorców ${ }^{109}$.

W latach późniejszych 20. i 30. wielokrotnie niezmiernie krytycznie oceniał polskie naśladownictwo wzorców zachodnich i związane z tym brak oryginalności i tzw. polskiej specyfiki, brak „twórczości narodowej”, stagnację polskiej myśli, rozkład moralny ${ }^{110}$. Pisał o złych konsekwencjach tego naśladowania: „Ta namiętność naśladownicza sprawia, że Polska, mająca dziś warunki do stania się jednym z najzdrowszych ustrojów społecznych, a z czasem jednym z najsilniejszych państw w Europie, chwieje się w swoich podstawach"111. Wskazywał, że „Polska położona na kresach cywilizacji zachodniej, młodsza cywilizacyjnie od zachodnich narodów, odznaczała się zawsze małą samodzielnością duchową, w słabej mierze żyła twórczością własną, a głównie zasilała się tym, co przychodziło z zachodu”. Stąd, jeśli na Zachodzie wystąpiła ,jałowość duchowa narodów”, to przeniosło się to wedle Dmowskiego także do Polski ${ }^{112}$.

W 1927 roku w pracy Zagadnienie rzadu pisał o narodzie polskim: „Jesteśmy narodem, który pod wieloma względami stoi daleko w tyle poza narodami, przodującymi w naszej cywilizacji. Nie mamy ich potęgi; ich obecnego bogactwa w przyszłości, o której zdolni jesteśmy konkretnie myśleć, nigdy mieć nie będziemy, tym mniej, że i one zaczynają je tracić; od poziomu ich kultury materialnej jesteśmy bardzo dalecy, dalecy też od stanu ich oświaty i bogactwa, dorobku umysłowego; co ważniejsza, nie mamy tej dyscypliny, tych silnych instynktów prawnych i społecznych, będących dziedzictwem ich tak różnej od naszej przeszłości.

109 Pisma, T. IV, s. 49 - „Nasze położenie geograficzne i nasz stosunek do cywilizacji zachodniej przez cały ciąg naszych dziejów, od przyjęcia chrześcijaństwa, sprawiał, żeśmy się trenowali w naśladownictwie wzorców obcych, form obcego życia. [...] Polska żyła przenoszeniem na swój grunt instytucji obcych, które tu, wobec innego ustroju społeczeństwa, przybierały często karykaturalną postać. I bodaj, że to jest najgłówniejszą przyczyną upadku państwa polskiego”.

110 Pisma, T. VI, s. 230 i n.; Pisma, T. IX, s. 118 i n.

111 Pisma, T. IX, s. 224.

112 Pisma, T. X, s. 138-139. Dmowski nawiązywał tutaj do teorii „młodszości” cywilizacyjnej Polski w stosunku do Zachodu, którą stworzył luminarz krakowskiej szkoły historycznej Józef Szujski, a którą później także głosił Michał Bobrzyński. 
Upokarza nas to, usiłujemy podążać za nimi, czasem przez rzetelną pracę i postęp, czasem przez płytkie, bezmyślne naśladownictwo. Nie uświadamiamy sobie wszakże należycie, że posiadamy pewne wielkie wartości, które tamtym narodom przydałyby się dzisiaj i uratowały je od wielu niebezpieczeństw, a które bądź nie wytworzyły się u nich w tej co u nas postaci, bądź też których pozbyły się one w ubiegłym okresie. Te wartości [...] to religia i poczucie narodowe, przywiązanie do ojczyzny, mające w sobie pierwiastek religijny, każący patrzeć na nią nie tylko jako na materialne, ale także, i to przede wszystkim, jako na moralne dobro" ${ }^{113}$. Pisał dalej, że z Zachodu Polacy powinno czerpać tylko to, co dobre, a odrzucać to, co złe ${ }^{114}$.

W 1930 roku Dmowski rozwinął szerzej wątek wzorców modernizacyjnych: „Historia nasza wytworzyła w nas nałóg czerpania mądrości z Zachodu. Do niedawna ten Zachód widzieliśmy głównie we Francji. W ostatnich czasach wpływy francuskie wypierane są szybko przez angielskie i amerykańskie. Dla licznej części mieszkańców naszego kraju najgodniejszymi naśladowania, czy też najdostępniejszymi były i pozostały wzory niemieckie. Anglia, Ameryka, Niemcy - właśnie narody głównie dziś zagrożone w swym ustroju gospodarczym i nie tylko gospodarczym. Konieczną jest rzeczą zastanowić się nad wartością idących stamtąd wpływów i przenoszonych na nasz grunt wzorów"115.

W 1934 podsumował swoje rozważania o polskich naśladownictwie i jego skutkach, o konieczności własnej pracy twórczej: „Jesteśmy narodem młodszym cywilizacyjnie od narodów zachodniej Europy. Skutkiem tego postęp cywilizacyjny u nas odbywał się nie dość samodzielnie, w głównej mierze polegał na naśladowaniu. Naśladowaliśmy wiele rzeczy dobrych, nieraz je psując i naśladowaliśmy złe. W ostatniej dobie, gdy europejska twórczość cywilizacyjna upadła, nasza, zdegradowana umysłowo, natomiast bardzo liczna inteligencja, nie posiadająca własnych sprawdzianów wartości cywilizacyjnych, nie umiejąca z siebie wydobyć żadnej poważniejszej twórczości, zeszła już zupełnie w swej masie na poziom [...] małp, bezmyślnie naśladujących wszystko, co obce, zarówno w swej pracy, jak w pojmowaniu życia, jak w upodobaniach, przyjemnościach, zabawie. Odbudo-

113 R. Dmowski, Zagadnienie rządu, Warszawa 1927, s. 16. Dla niego religia katolicka miała być odtrutką czy też parasolem ochronnym dla Polski wobec złych, negatywnych wpływów masonerii, którą „zaraziły” się już kraje zachodnie (Pisma, T. IX, s. 118-119). Pisał o obowiązkach współdziałania z czynnikami kościelnymi „w ich dążeniu do wzmocnienia i podniesienia na wyższy poziom życia katolickiego w społeczeństwie, do osiągnięcia należytej roli dla religii i Kościoła w życiu narodu i państwa” (ibidem, s. 153-154).

114 R. Dmowski, Zagadnienie rzadu, s. 26.

115 Pisma, T. VII, s. 50. 
wanie Polski było w znacznej mierze zaprowadzeniem w Polsce Ameryki, która byłaby się o wiele bujniej rozwinęła, gdyby pieniędzy nie zabrakło. Ileż to paskudztw i głupstw przeniknęło do Polski od czasu jej odbudowania, często nie za sprawą złych skłonności, ile bezmyślnego naśladownictwa. Tymczasem życie dotychczasowe w ogromnej części się zawala - trzeba tworzyć nowe. Tworzyć je musi samodzielna myśl polska. Bo kraje zachodnie, wyjałowione w okresie ubiegłym, same na potrzebną twórczość zdobyć się nie mogą, a gdyby nawet mogły, to wobec innej postaci, jaką przybierają w nich zagadnienia dzisiejszej doby, niewiele byśmy z ich twórczości skorzystali”"116. Wypowiedź ta nawiązuje do ogólnie znanej teorii młodszości cywilizacyjnej, która zaistniała w polskiej myśli politycznej już w II połowie XIX w., chociażby w twórczości tzw. krakowskiej szkoły historycznej.

Dmowski przy wielu okazjach podkreślał oryginalność, samodzielność swojej myśli i swojego obozu politycznego, twórczą kreatywność ${ }^{117}$. Był to zabieg celowy, który miał pokazać „lepszą jakość” endecji w stosunku do innych obozów i grup politycznych, naśladujących „bezmyślnie” Zachód: „bo Obóz Narodowy w Polsce nie był naśladowaniem żadnej organizacji politycznej w innych krajach, a idee jego nie były bezmyślnie importowanym z zagranicy towarem. Był to wynik ciągle postępującej, samodzielnej pracy myśli polskiej, której bodźcem było silne, dumnie się wypowiadające przywiązanie do ojczyzny" 118 .

Niełatwo jest jednoznacznie ocenić twórczość, pisarstwo Romana Dmowskiego. Dla wielu był kontrowersyjnym pisarzem politycznym. Z jednej strony widział on w Żydach „sprawców” wszelkich nieszczęść Polski, tak przeszłych (rozbiory i upadek Rzeczypospolitej), jak i teraźniejszych, autorów upadku obyczajów, kryzysu gospodarczego etc. Często u niego występowała modna w obozie narodowym zbitka pojęciowa "Żyd = mason = finansista”, a niezbyt miłe dlań rządy parlamentarne w Polsce i na świecie utożsamiał wprost z masonerią i Żydami! ${ }^{119}$. Z drugiej strony Dmowski jawił się jako znakomity obserwator rzeczywistości społecznej, przenikli-

116 Pisma, T. IX, s. 313-314.

117 Przykładowo: Pisma, T. IV, s. 70; T. V, s. 167; T. VIII, s. 442-443; T. X, s. 199-200, 238-239.

118 Pisma, T. X, s. 238-239.

119 Roman Wapiński podkreślał, że w tej fazie życia Dmowski tłumaczył wiele zjawisk społecznych za pomocą „spiskowej teorii historii” (spiskowa teoria dziejów): przykładowo mówił o „międzynarodowym spisku żydowskim”, który równocześnie miał współdziałać w rozwoju rewolucji bolszewickiej i działaniach kapitalistów zachodnich. Zob. R. Wapiński, Narodowa Demokracja 1893-1939..., s. 152, 155 oraz idem, Roman Dmowski, s. 320. 
wy i odważny krytyk, poliglota, człowiek obyty w świecie, który lubił podróżować, poznawać nowe kraje i ludzi ${ }^{120}$. W jego pracach z lat 20. i 30. można znaleźć wiele trafnych uwag $\mathrm{m}$. in. o fatalnych skutkach moralnych i psychicznych I wojny światowej na społeczeństwa, dynamicznym rozwoju gospodarczym państw pozaeuropejskich (Stany Zjednoczone, Japonia, Chiny, Brazylia), upadku moralności, o rozwoju techniki, o militaryzacji polityki (zwłaszcza w Niemczech i we Włoszech), o produkcji masowej i wytwarzaniu „tandety” etc. Niezwykle trafnie scharakteryzował publicystykę Dmowskiego lat 20. i 30. jego biograf, Krzysztof Kawalec: „Tendencja do postrzegania rzeczywistości w sposób zdeformowany uprzedzeniami i mitologią ścierała się z poczuciem umiaru i rozsądkiem [...] Jako pisarz polityczny, Dmowski miał już najlepsze lata za sobą. Bez wielkiego trudu można łowić w jego powojennej twórczości zarówno pochopne uogólnienia, zbyt śmiałe, a wypowiadane w kategorycznym tonie prognozy na temat przyszłości często odległej, jak i trącące irracjonalizmem spekulacje dotyczące dziedzin, gdzie nie sposób o udokumentowane sądy. Dotyczy to w szczególności opinii na temat poczynań oraz powiązań organizacji tajnych. Równocześnie jednak ciągle trafić w niej można na spostrzeżenia budzące respekt dla przenikliwości ich autora. Dmowski był bliski czasom nam współczesnym w tym, że w ocenie rozmaitych zjawisk świadomie starał się uwolnić od presji dominującego w jego epoce europocentryzmu"121.

Z pewnością nie można propozycji modernizacyjnych Romana Dmowskiego rozpatrywać w kategoriach powstałych po II wojnie światowej teorii modernizacji jako zwartych, spójnych systemów - w takim rozumieniu, jakie nadała temu pojęciu socjologia współczesna. Zresztą po 1918 roku tj. w niepodległej Polsce, miał najlepsze lata działalności pisarskiej (w sensie jakościowym) za sobą. Jak już wyżej nadmieniono, nie miał on głębszej znajomości zagadnień ekonomii.

Jaka wedle Romana Dmowskiego miała być nowoczesna Polska? Byłoby to zapewne „tanie” państwo, z gospodarką kapitalistyczną, wolnym rynkiem i poszanowaniem własności prywatnej, ze zredukowanym ustawodawstwem społecznym, z rozwiniętym przemysłem i rolnictwem, z silną klasą średnią, z ograniczoną machiną biurokratyczną, państwo narodowe z ograniczeniem praw mniejszości

120 Dmowski zwiedził m.in. Europę (Francja, Szwajcaria, Austria, Węgry, Wielka Brytania, Włochy, Dania, Szwecja, Niemcy, Czechy), Amerykę Północną (USA, Kanada), Amerykę Południową (Brazylia), Azję (Japonia), Afrykę (Algieria). Opanował kilka języków obcych (czynnie lub biernie, w stopniu co najmniej przyzwoitym) język francuski, angielski, niemiecki, rosyjski, hiszpański, włoski etc. Dał świetną próbkę znajomości angielskiego i francuskiego w czasie obrad Konferencji Pokojowej, na posiedzeniu Rady Dziesięciu z 29 stycznia 1919 roku, zob. M. Kułakowski [Józef Zieliński], op. cit., s. 315; K. Kawalec, Roman Dmowski..., s. 52; R. Wapiński, Roman Dmowski, s. 270.

121 K. Kawalec, Roman Dmowski..., s. 233 oraz interesująco: E. Maj, op. cit., s. 120. 
narodowych, z niską liczbą ludności żydowskiej, dyskryminowanej intensywnie na płaszczyźnie gospodarczej, z ograniczeniem uprawnień władzy ustawodawczej i z silną władzą wykonawczą, z powiązaniem polskości z katolicyzmem i silnym akcentowaniem obecności religii katolickiej w życiu społecznym itd. Część jego pomysłów na modernizację polskiego życia gospodarczego nie była zła („tanie” państwo, wprowadzenie oszczędności i redukcja nadmiernie rozbudowanej machiny biurokratycznej, rozwój przemysłu i rolnictwa, walka ze spekulacją), jednak często były to propozycje nazbyt ogólnikowe czy niejasne, część pomysłów miała charakter wybitnie wolnorynkowy i z tej racji nie miała szans na realizację czy popularność w atmosferze lat 20. i 30. (redukcja nadmiernie jego zdaniem rozbudowanego ustawodawstwa społecznego), a część jawnie uderzała w ludność żydowska i miała wybitnie antysemicki charakter. Podobnie były z postulatami w sferze ustroju Polski i polskiego życia politycznego: mieszają się postulaty „pozytywne” (uzdrowienie/umoralnienie polskiego życia politycznego, podniesienie poziomu kultury politycznej polskich elit politycznych i polskiego społeczeństwa, zmiana konstytucji, wzmocnienie władzy wykonawczej) z postulatami „negatywnymi” bądź kontrowersyjnymi (założenie Obozu Wielkiej Polski, powiązanie polskości z katolicyzmem i jego instrumentalne traktowanie, zorganizowanie narodu, uczynienie z Polski państwa narodowego, chęć odejścia od rządów parlamentarnych, postulat usunięcia nadmiaru ludności żydowskiej w Polsce) - część z tych pomysłów, była mglista, enigmatyczna, a ich realizacja w warunkach międzywojennej Polski z pewnością groziłaby konfliktami narodowościowymi i społecznymi. Najmniej kontrowersyjne wydają się być postulaty w dziedzinie modernizacji społeczeństwa, jego mentalności (przywiązania do praworządności, podniesienie kulturalne i cywilizacyjne warstw najniższych, dbałość o kluczową dla społeczeństwa instytucję rodziny, większa aktywizacja w życiu społecznym Polski najbardziej ucywilizowanych grup polskiej ludności z ziem dawnego zaboru pruskiego, zwiększenie pracowitości Polaków, nauka pozytywnej rywalizacji czy umiejętności konkurowania, postulat uświadamiania ludności o problemach gospodarczych i społecznych, akcent na własną twórczość, własną kreatywność). Nie da się jednoznacznie ocenić wszystkich przytoczonych wyżej postulatów modernizacyjnych Dmowskiego - cechuje je, podobnie jak i całą twórczość Dmowskiego, pewne „rozdwojenie” - przeplatają się pomysły kontrowersyjne z koncepcjami ciekawymi, czasem oryginalnymi. Ogólnie występowały u niego trudności ze zrozumieniem realiów świata po Wielkiej Wojnie. Trzeba to podkreślić, chociaż bezsporne jest, że nie tylko u niego - wśród ówczesnych elit - dostrzeżemy takie słabości.

Wypada zakończyć te wywody jeszcze jedną wypowiedzią Dmowskiego, która dobrze ilustruje jego „rozdwojony”, ambiwalentny stosunek do nowoczesności 
i związanych z nią relacji Polska-Europa: „Dziwnym zdarzeniem losu, w którym bodaj więcej było logiki, niż się na pozór może wydawać, przez ciąg okresu, w którym Europa była u szczytu swej potęgi, bogactwa i panowania nad światem, Polska była wykreślona z jej karty, a powróciła na nią, odzyskała samoistną rolę w świecie, dopiero w chwili, kiedy się rozpoczął upadek naszej części świata. [...] Fakt, żeśmy byli nieobecni w Europie w ciągu ubiegłego okresu, sprawił, że jesteśmy dziś o wiele mniej Europą, niżbyśmy byli, gdybyśmy mieli w XIX w. własne państwo. Straciliśmy przez to wiele: skurczył się nasz obszar narodowy, kraj się strasznie zażydził, jesteśmy biedni, politycznie dziecinni, nie mamy należytej dyscypliny, nie umiemy szanować prawa, nie umiemy rządzić... Ale czy tylko straciliśmy ?... Czy wszystko, co wiek dziewiętnasty dał Europie, a od czego myśmy byli w znacznej mierze odsunięci, przedstawiało tak niewątpliwą wartość?... Dziś widzimy, że ten szalony rozrost industrializmu, który dawał Europie bogactwo, zamienia się w klęskę; że wysoka kultura materialna, nawyknienie do dobrobytu i komfortu utrudnia jej współzawodnictwo gospodarcze z krajami niższej kultury; że typ oświaty, który się tam w masach rozszerzył, zrodził w nich wstręt do prostej pracy, wypędza je ze wsi i zapełnia miasta ludnością, stanowiącą coraz większy ciężar dla społeczeństwa; że ten typ oświaty, to nawyknienie do dobrobytu i wyrastająca na tym gruncie, przy upadku religii, coraz większa chęć używania pociąga za sobą szybki upadek urodzeń, a z nim kurczenie się liczebne narodów; że szczycące się wspaniałymi instytucjami, znakomicie obsłużone państwo nowoczesne, stało się o wiele za kosztownym, ażeby je narody przy obecnych swych środkach zdolne były utrzymać; że wybujały parlamentaryzm, który sobie Europa w ciągu XIX wieku wytworzyła, uniemożliwia sensowną gospodarkę państwową, zgodną ze środkami społeczeństwa [...] Myśmy tę świetną dobę, ten XIX wiek, przeżyli tylko w małej części i te dolegliwości w krew nam nie weszły. Prawda, że po odbudowaniu państwa, nie z żadnej konieczności, ale po prostu przez małpie naśladownictwo, w przekonaniu, że tym swojemu krajowi największe wyświadczymy dobrodziejstwa, znaczną ich część zdążyliśmy już na swój grunt przeszczepić - ale zaszczepiliśmy je dość powierzchownie. Pod naciskiem wymagań życia i pod wpływem zdrowego rozsądku, który jednak robi szybkie u nas postępy, będziemy bodaj umieli wielu z tych naleciałości się pozbyć. Przywiązanie do cywilizacji europejskiej nie powinno przekraczać zdrowych, sensownych granic: nie trzeba dobrowolnie skazywać się na dzielenie z Europą tych cierpień, od których my możemy być wolni, dlatego właśnie, żeśmy nie dzielili jej powodzeń i owoców ich nie używali"122.

122 Pisma, T. VII, s. 333-335. 